\title{
Seagrass-related carbonate ramp development at the front of a fan delta (Burdigalian, New Caledonia): Insights into mixed carbonate-siliciclastic environments
}

\author{
Tournadour Elsa 1, 2, ${ }^{*}$, Fournier F. ${ }^{3}$, Etienne S. 1, 2 , Collot Julien ${ }^{2}$, Maurizot P. ${ }^{2}$, Patriat Martin 4,
} Sevin B. ${ }^{2}$, Morgans H.E.G. ${ }^{5}$, Martin-Garin B. ${ }^{3}$, Braga J.C. 6

\author{
${ }_{1}^{1}$ Adecal Technopole, 1 bis Rue Berthelot, Doniambo, B.P. 2384-98 846, Nouméa, New Caledonia \\ 2 Service Géologique de Nouvelle-Calédonie, DIMENC, B.P. 465, 98845, Nouméa, New Caledonia \\ ${ }^{3}$ Aix Marseille Univ, CNRS, IRD, INRAE, Coll France, CEREGE, Case 67, 3, 13331, Marseille Cedex \\ 03, France \\ ${ }^{4}$ IFREMER, Unité Géosciences Marines, 29280, Plouzané, France \\ 5 GNS Sciences, PO Box 30368, Lower Hutt, 5040, New Zealand \\ 6 Universidad de Granada, Departamento de Estratigrafía y Paleontología, Avenida de La Fuente \\ Nueva, 18071, Granada, Spain
}

*Corresponding author : Elsa Tournadour, email address : elsa.tournadour@gouv.nc

\begin{abstract}
:
Past shallow-water carbonate environments of the main island of New Caledonia (NC) have been subject to high terrigenous influx derived from the erosion of ultramafic obducted nappes and are therefore a relevant case study for characterizing neritic carbonate production in mixed carbonate-siliciclastic systems under a tropical climate. More particularly, we focused on Burdigalian carbonate sedimentary records cropping out on the western coast of NC, in the Népoui area. Based on a comprehensive sedimentological study of cores and outcrops, we established a new depositional model of an alluvial fan to carbonate ramp transition. Shallow-water (euphotic) carbonate production was dominated by seagrassrelated biota and corals derived from small-sized bioconstructions. Extensional tectonics and associated normal faulting, driven by post-obduction isostatic rebound, favored carbonate ramp aggradation and preservation. The carbonate ramp was incised by conglomerate-filled terminal distributary channels, which indicate that terrigenous inputs remained significant during marine transgression and did not inhibit the development of seagrass and scleractinian carbonate factories. Phytal substrates induced by seagrass and/or macro-algae seafloor colonization strongly controlled the nature of carbonate production and promoted the accumulation of foraminiferal-coralline algal sediments. Seagrass development at the front of the fan delta is interpreted to have controlled the preservation of a diverse and significant carbonate production by reducing water turbidity and by limiting the risk of suffocation for filter-feeding biota in such a high terrigenous influx setting.
\end{abstract}




\section{Highlights}

- Extensive development of seagrass carbonates occurs at the front of tropical fan delta. $>$ Seagrass meadows development favored carbonate production and preservation. The long-term preservation of the depositional system is due to the post-obduction subsidence regime.

Keywords : Miocene, seagrass, tropical carbonates, terrigenous inputs, alluvial fan, facies association, New Caledonia 


\section{INTRODUCTION}

44 Mixed carbonate-siliciclastic depositional systems are characterized by a high vertical and

45 lateral variability in facies and lithologies, which results from the interplay between carbonate

46 production and terrigenous supply. Such complexity makes difficult the sequence stratigraphic

47 interpretation of mixed systems (Zeller et al., 2015) and complicates the prediction of reservoir

48 architectures from subsurface data (McNeill et al., 2004).

49 Mixed systems have been commonly subdivided into temporal phases of either dominant

50 carbonate or siliciclastic deposition by applying the concepts of reciprocal sedimentation

51 (Wilson, 1967). According to this model, siliciclastic deposits prevail during low sea level

52 periods whereas carbonate facies dominate during transgressions and highstands. However, this

53 model, often used in ancient case studies (e.g. Permian Capitan margin: Silver \& Todd, 1969;

54 Kerans \& Tinker, 1999) has been shown to be inadequate for describing several quaternary (e.g.

55 Great Barrier Reef: Page et al., 2003; Harper et al., 2015; New Caledonia: Le Roy et al., 2019) and

56 ancient mixed carbonate-siliciclastic systems (e.g. Late Jurassic northeastern France: Olivier et

57 al., 2004; Jurassic-Cretaceous Neuquén basin, Argentina: Zeller et al., 2015). The deviations from 
the reciprocal sedimentation model may be related to increased siliciclastic inputs during transgression as a result of regional climate changes, reworking and dispersing of previously deposited terrigenous sediments (Harper et al., 2015) or steeper fluvial profile compared to shoreline trajectory (Catuneanu, 2019). In addition, continued high carbonate production during sea level lowstands and/or periods of high terrigenous inputs go against the applicability of reciprocal sedimentation concepts (Zeller et al., 2015). Carbonate production and the nature of carbonate producers are therefore a key parameter to be considered for the prediction of depositional models and stratigraphic architectures in mixed systems. Moreover such predictions are complicated by the interplay between carbonate production and siliciclastic inputs. Terrigenous influx is known to be a significant factor controlling carbonate production since it leads to increased water turbidity, thus reducing available light for light-dependent organisms and to suffocation of filter-feeding biota due to high sedimentation regimes (e.g. Rogers 1990; Fabricius 2005). Many studies have shown that prolonged exposure to terrigenous discharge from rivers has a negative impact on shallow-water carbonate production, particularly in coral reefs (Rogers 1990; Van Katwijk et al. 1993; Fabricius 2005). In contrast, such a negative impact of terrigenous inputs on neritic carbonate production has been contradicted in different Quaternary and ancient tropical carbonate systems from the Indo-Pacific (e.g. Wilson, 2005; Perry et al., 2012; Novak and Renema, 2015; Santodomingo et al., 2015) and Mediterranean domains (e.g. Corsica: Tomassetti et al., 2013; Sardinia: Vigorito et al., 2012; Ligurian Alps: Brandano et al., 2015; Turkey: Bassant et al., 2005), and many examples of barrier-reef systems developing on terrigenous shelves were documented in modern environments (The Great Barrier Reef in Australia: e.g. Belperio, 1983; Orpin et al., 2004; Puerto-Rico: Ryan-Mishkin et al., 2009; Belize shelf: Mc Neill et al., 2010; Gulf of Mexico: Hernandez-Arana et al., 2015). These numerous examples have demonstrated the great capacity of photozoan, coralgal production to adapt to strong terrigenous inputs. However, even though seagrass-related biota has been reported in various mixed carbonate-siliciclastic systems (e.g. Reuter et al., 2011; Sola et al., 2013; Beavington-Penney et al., 2004), relatively low attention has been paid on the resilience of 
seagrass carbonate factories to strong terrigenous discharges (Mateu-Vicens et al., 2012). Additionnaly, although Cenozoic seagrass deposits are well known from the Caribbean (Eva, 1980), the Mediterranean (e.g. Mateu-Vicens et al., 2008; Brandano et al., 2009; Bassi and Nebelsick, 2010; Sola et al., 2013; Tomassetti et al., 2016) to the Indo-Pacific (e.g. Chaproniere, 1975; Beavington-Penney et al., 2004; Reuter et al., 2011; Haig et al., 2020) areas, complete depositional models of seagrass-influenced carbonate systems subject to high terrigenous supplies are lacking.

The Upper Népoui Formation (Burdigalian), cropping out on the western margin of New Caledonia (South-West Pacific), is a mixed shallow-marine depositional system where continuous terrigenous inputs derived from post-obduction erosion of ultramafic nappes were supplied into shallow-water ramp environments where a significant seagrass-related, and scleractinian carbonate production occurred (Maurizot et al., 2016). Such spatially wellconstrained outcrops thus represent a relevant case study for understanding the ecological and physical processes that control the architecture and evolution of tropical, seagrass-dominated carbonate systems which are subject to high terrigenous supplies.

A comprehensive sedimentological study of the Burdigalian mixed system has been performed, based on newly acquired core data as well as new outcrop descriptions. On the basis of the detailed geological mapping and logging of sedimentary units, coupled with micro- and macroscale petrographic and sedimentological characterisation of the carbonate and terrigenous deposits, the present work aims at: 1) constructing an original depositional model of the transition from an alluvial-fan to a seagrass-dominated carbonate ramp, 2) assessing the role of potential controlling factors such as relative sea level fluctuations, nutrient supplies and water turbidity on the depositional architecture of mixed carbonate-siliciclastic systems, and 3) discussing the significance of seagrass-related carbonate factories in tropical environments subject to high-terrigenous influx. 
111 The resulting depositional architecture constitutes a valid and original model for potential

112 hydrocarbon reservoirs in mixed carbonate-siliciclastic ramps forming in tropical setting.

\section{GEOLOGICAL SETTING}

115

\subsection{Geodynamic framework of the New Caledonian western margin}

The New Caledonian main island, Grande Terre, is located in the South West Pacific (Fig.1), at the north-eastern tip of Zealandia, a large and mostly submerged piece of thinned continental crust inherited from the cretaceous break-up of eastern Gondwana (Mortimer et al., 2017). Indeed, from Late Cretaceous to Paleocene, a rifting phase followed by seafloor spreading in Tasman Sea led to the isolation of Zealandia (Gaina et al., 1998). During the Eocene, New Caledonia underwent a convergence phase that led to the NE-SW emplacement of various nappes, including the prominent mantellic Peridotite Nappe (Paris, 1981; Cluzel et al., 1994; Aitchison et al., 1995; Cluzel et al., 2001; Cluzel et al., 2012). During obduction, the New Caledonia Basin, which is located west of Grande Terre, reacted as an asymmetrical flexural basin, and is now filled by $6 \mathrm{~km}$-thick post-obduction sediments (Collot et al., 2008).

The tectonic and sedimentary evolution of Grande Terre during the post-obduction period (Oligocene-present) remains debated. Most authors agree that this period is characterized by an uplift of Grande Terre driven by post-obduction isostatic rebound (Moretti \& Turcotte 1985, Lagabrielle \& Chauvet, 2008, Collot et al., 2017). This uplift is interpreted as being at the origin of the collapse of both the western and eastern margins through large scale normal faults together with the development of a deepwater fold and thrust belt at the foot of the western margin of New Caledonia (Lagabrielle \& Chauvet, 2008, Collot et al., 2017). However, based on the subduction-related geochemical signatures of the Koum and St Louis granitoids intruding the Peridotite Nappe, Cluzel et al. (2005) and Paquette and Cluzel (2007) suggested that a short- 
137

lived east-dipping Oligocene subduction of the New Caledonia Basin occurred beneath Grande Terre.

More recently, since the Plio-Quaternary, Grande Terre has been also affected by antithetic vertical motions between its western and southeastern margins. Indeed, based on drillings performed both on fringing reefs and on the barrier reef, Cabioch et al. (1999) suggested that a subsidence of the western margin of New Caledonia allowed the aggradation of the barrier reef and the associated lagoon. Montaggioni et al. (2011) estimated this subsidence to be higher than $0.08 \mathrm{~mm} \cdot \mathrm{yr}^{-1}$ since $1 \mathrm{Ma}$ ago. Conversely, along the southeastern margin of New Caledonia, a ca. $10 \mathrm{~m}$ uplift of reefs is observed in the area of Yaté and Pines Island (Cabioch et al., 1996). These reef uplifting is thought to be the result of the flexure of the lithospheric plate entering into the New Hebrides subduction (Dubois et al., 1974; Lafoy et al., 1995).

\subsection{Geological setting of the Népoui area}

The mixed siliciclastic carbonate deposits of the Népoui Group crop out along the western margin of New Caledonia, in front of the peridotite massifs of Kopéto and Boulinda. They unconformably rest on both the Népoui Eocene Flysch and the Poya Terrane (Figs.2A and B). The Népoui Flysch, dated from the late Eocene by micropaleontologic analyses, is considered as a syn-obduction formation based on its mafic lithological composition and its deformed state (Cluzel et al., 1998). It constitutes the youngest formation located beneath the allochtonous Peridotite Nappe, which would constrains the oldest possible age of the end of obduction at 34 Ma. The Poya Terrane comprises mid ocean ridge basalts and abyssal sediments, dated from the Late Cretaceous to the latest Paleocene based on radiolarian fauna, and is situated at the base of the Peridotite Nappe (Paris, 1981; Cluzel et al., 1997) (Figs.2A and 2B).

First descriptions of the Népoui Group considered a relatively simple vertical succession involving a lower fluvio-deltaic unit, named the Pindaï Conglomerates, overlain by shallow 
164

165

166

167

168

169

170

171

172

173

174

175

176

177

178

188 Finally, the post-Burdigalian Muéo Formation unconformably rests on the Népoui Upper

189 Formation on the Pindaï and Muéo peninsulas (Fig.2A). It primarily comprises extensive lateritic

marine limestones, initially attributed to the Early to Middle Miocene (Gubler \& Pomeyrol, 1948 ; Coudray, 1975 ; Paris, 1981) (Figs.2A and B). More recently, Maurizot et al. (2016) discovered a new limestone unit below the Pindaï Conglomerates, on the Chapeau Chinois outcrops and in the 103 m deep S4 well (see location on Fig. 2), which reached the unconformity separating post-obduction miocene deposits from the syn-obduction eocene Népoui Flysch (Fig.2B and Fig.3). These authors consequently subdivided the mixed system of Népoui into three formations and restricted the lower limestone formation to the Aquitanian and the upper limestone formation to the Burdigalian based on six strontium isotope measurements perfomed on preserved Mg-calcite from echinoid spines, combined with benthic and planktonic foraminiferal biostratigraphy (Fig. 3). The lower formation (Lower Népoui Formation) is a dominantly carbonate interval composed of three members, from base to top: the A1 Chapeau Chinois Member, the A2 Operculina Green Sands Member and the A3 Xuudhen Limestone Member (Fig. 3). Above, the strictly siliciclastic, fluvio-deltaic Pindaï Conglomerate Formation, is assigned to the Burdigalian, yet no direct biostratigraphic or radiometric datings were performed on that interval. The upper formation (Upper Népoui Formation) is made of mixed carbonate-siliciclastic, shallow water deposits, Burdigalian in age, which are subdivided into two members: the Wharf Member and the Népü Limestone Member (Fig. 3). In this paper, we argue that the Pindaï Conglomerates are part of the Upper Népoui Formation, similarly to the lithostratigraphic framework proposed by Sevin et al. (2014). Following this scheme, the Upper Népoui Formation comprises the B1 Pindaï Conglomerate Member, the B2 Wharf Member and the B3 Népü Limestone Member (Fig. 3). A dominant seagrass-related carbonate production prevailed in the euphotic area of the Aquitanian and Burdigalian ramps (Maurizot et al., 2016), even though scattered scleractinian colonies are common in both systems. red muds with large silicified blocks and reworked lateritic ferricretes (Paris, 1981). In former 
191 studies, this formation was correlated with the Pindaï conglomerates, which led to some degree

192 of confusion (Paris, 1981).

193

194 In the offshore domain, seismic profiles revealed a $200 \mathrm{~km}$ along-margin and $50 \mathrm{~km}$ into the

195 basin deepwater fold and thrust belt in front of the Népoui area, interpreted as being gravity

196 driven (Rigolot \& Pelletier, 1988; Collot et al., 2017) (Fig.1). Faults associated with this failure

197 are deeply rooted in the New Caledonia Basin (ca. $5 \mathrm{~km}$ depth) and are interpreted as being in

198 continuity with major detachments onshore that is in agreement with the extensional tectonic

199 model suggested by Lagabrielle \& Chauvet (2008). 


\section{DATA AND METHODS}

201 Outcrops of the Népoui Group are restricted to an area of about $100 \mathrm{~km}^{2}$ that includes the

202 Pindaï, Muéo, Nékoro, and Béco peninsulas, as well as the islands and islets of Grimault, Didot and Longue (Fig.4). This study focused on the Burdigalian Upper Nepoui Formation (Fig.3). The overall stratigraphic succession is $80 \mathrm{~m}$-thick and is slightly tilted $\left(<10^{\circ}\right)$ towards the SSW, i.e. towards the present day lagoon and Quaternary barrier reef (Fig.2). The most recent study dedicated to the Népoui Group was based on the description of a 103 m deep cored well, S4, in combination with its stratigraphic continuity exposed on the outcrops of the Chapeau Chinois and Wharf areas (Maurizot et al., 2016) (Fig. 4). In order to improve the architectural characterization of the Upper Népoui Formation (Burdigalian), the existing dataset was complemented by a new, 170 m-long cored well, S2 (Fig. 4). The latter is located only a few kilometers away from the main outcrops of the Pindaï peninsula and reveals the spatial variability system in a proximal to distal direction, following a NNE-SSW transect. Additionally, we included nine shallower drilled boreholes (20 to $30 \mathrm{~m}$ long) and detailed sedimentological descriptions of coastline outcrops of the Pindaï and Beco peninsula and of the Grimault, Didot and Longue islets, in order to constrain the depositional models and the stratigraphic architectures (Fig. 4). Based on this new dataset, we performed a detailed sedimentological analysis at the 1:50 scale using a classical "facies association" approach (eg. Allen, 1983; Miall, 1985; Posamentier \& Walker, 2006). The outcrops and S2 core data were investigated by logging 7 key sections, which were summarized in 1:500 scale synthetic logs presented in Fig. 18. Depositional facies were defined based on sedimentary structures, depositional textures and biological composition identified from outcrops, cores and thin-sections. A total of 100 thinsections from the Upper Népoui formation were used for microfacies characterization (texture, skeletal composition, diagenetic features). Additionally, 22 thin-sections were point-counted by using the JMicroVision software on the basis of 300 points to quantify the bioclastic composition of the sand-grained skeletal fraction of carbonates. Facies were grouped into facies associations, 
227 stratigraphic distribution of facies associations allowed a well-constrained depositional model to 228 be proposed. 


\section{RESULTS}

\subsection{Facies association analysis}

231 The Upper Népoui Formation is a lithologically heterogeneous and sedimentologically complex succession. The spatial and vertical distribution of the sedimentary facies, together with their stacking patterns further permits to gather them into eight facies associations that are thought to reflect distinctive depositional environments (Fig. 5). We identify continental deposits (FA1, FA2 and FA3) within the B1 Member of the Pindaï Conglomerates, shallow-marine sandstone deposits (FA4 and FA5) for the B2 Wharf Member and shallow-water carbonate deposits (FA6, FA7, FA8) typifying the B3 Népü Limestone Member. These facies associations are detailed in the following sections.

\section{FA1- Proximal alluvial fan (Fig. 6)}

Description: in the northeastern part of the Pindaï Peninsula and on the Muéo Peninsula along the "piste de roulage" outcrops (see location Fig. 4), the Pindaï Conglomerates display wellrounded, moderately- to poorly-sorted pebbles in a coarse- to fine-grained sandy matrix (Fig. 6A). These polygenic conglomerates are composed of mafic and ultramafic clasts (serpentinites, serpentinised peridotites, dolerites, gabbros) as well as ferricrete clasts. They can reach $1 \mathrm{~m}$ in diameter but their average size is $30-40 \mathrm{~cm}$ (Fig. 6A, B and C). In the western part of the Muéo Peninsula, these conglomerates rest unconformably on the Népoui Eocene Flysch (Fig. 6E and 6F). Two fining upward conglomeratic to sandy successions are here exposed. They comprise matrix-supported, disorganized to normally graded conglomerates with erosive base, that evolve vertically towards gravelly sandstones with faint trough cross-bedding highlighted by 251 gravels and pebbles (Fig. 6D and 6F). Although pebble orientation is in most places chaotic, a 252 preferential north-dipping clast imbrication is observed, suggesting a north to south dominant 253 transport. This orientation is confirmed by the presence of $\mathrm{N} 20^{\circ}$ oriented groove marks at the 254 base of the second fining upward succession. 
Interpretation: within the conglomeratic facies, the matrix-supported fabric, poor sorting of

clasts combined with the apparent lack of tractive sedimentary structures are consistent with

subaerial debris flow processes (Blair \& McPherson 1994; Blair 1999). In turn, more structured

conglomerates and overlying cross-bedded gravelly sandstones are consistent with bedload

transport and tractive deposition by high density flows, and would possibly correspond to

braided-river barforms (Bluck, 1979; Miall, 1985). We therefore interpret this facies association

as recording deposition within the proximal part of an alluvial fan, where surficial braided distributary channels can develop on top of alluvial fan debris flow lobes (e.g. sheetflood dominated alluvial-fan model of Blair \& McPherson, 1994). The lack of preserved floodplain deposits is an additional evidence to favor an alluvial fan setting over a fluvial channel belt. In addition, the lack of angular clasts in these facies is of note. Here, the subrounded to rounded character of boulders and pebbles does not appear to be directly linked with flow transport distance. Indeed, weathering of peridotites under a humid tropical climate can promote the in situ formation of rounded blocks in saprolite layers (Trescases, 1975) (Fig. 6B). However, in the absence of valuable geometrical constraints due to outcrop discontinuity, an alternative interpretation where structureless conglomerates represent the basal part of channel-fills rather than unconfined debris-flow lobes cannot be entirely ruled out.

\section{FA2- Distal alluvial fan (Fig. 7)}

Description: in the East of the Pindaï Peninsula, the basal part of the Wharf outcrops (see location Fig. 4) exhibits a fining and thinning upward succession whose base consists in pebblecobble ( 2 to $15 \mathrm{~cm}$ in diameter) oblique bedded conglomerates, in places with pebbles preserved as residual vugs ("ghost pebbles"), within a coarse-grained sandstone matrix with floating granules (Fig. 7A and 7B). Several decimeter-thick intervals of normally graded, coarse-grained trough cross-bedded sandstones with granules overlie these conglomerates. The whole succession is organized as meter-scale oblique bedsets with dips of around $15-20^{\circ}$ toward the 
SSW (Fig. 7B). The succession is topped by red to greenish-red medium to fine-grained trough cross-bedded sandstones (Fig. 7C) capped by a traceable surface highlighted by numerous roots and iron oxide concretions (Fig. 7A and 7D).

Interpretation: similarly to FA1, oblique bedded conglomerates can be interpreted as sandgravel bars formed by the sediment discharge of a unidirectional high capacity flow (Allen, 1983; Miall, 1985). Trough cross-bedded sandstones are consistent with fluvial settings and are typically assigned to three dimensional dunes (Allen, 1963; Allen, 1983) which may be interpreted to develop as frontal splays of alluvial fans. In our case, the SSW orientation of bedsets, parallel to the known general transport direction, together with the grading of sandstones points to a downstream accretion of deposits at the mouth of a stream channel alluvial fan rather than lateral accretion within a river channel belt. At the top of the succession, the decrease in grain size, increase in plant debris, root traces and iron concretions can be interpreted as a planar abandonment surface and are consistent with paleosol development. This facies association is therefore interpreted as a recording deposition within the distal part of alluvial fans.

\section{FA3- Fluvial channel-fills (Fig. 8)}

Description: at the north easternmost extremity of the Didot Islet (see location Fig.4), an isolated, erosive based, $5 \mathrm{~m}$-thick conglomerate succession is exposed (Fig. 8A and 8B: channel 1). It comprises polygenic, mafic and ultramafic, 5 to $6 \mathrm{~cm}$ in diameter pebbles within a coarse- to very coarse-grained sandy matrix organized in graded beds with erosional trough-shaped bases, and meter-scale oblique sets, with a dominant SSE orientation (Fig. 8C). These deposits contain numerous and large silicified wood fragments (Fig. 8D) including trunks, up to $1 \mathrm{~m}$ long. Laterally, only a few tens of meters westwards, a similar 10 m-thick succession occurs (channel 2: Fig.8A). Both successions are overlain by an alternation of marly deposits and centimeter- 
thick, fine- to very fine-grained calcareous sandstones with undifferentiated bioclasts and foraminifers (Fig. 8A).

Interpretation: these well-structured conglomerates are interpreted as resulting from bedload transport, most likely within a coarse braided river system (Allen, 1963; Miall, 1977). Indeed, within such isolated channel-fills, individual trough cross-bedded sandstones record distinct phases of the channel fill. These small scale channel fills are interpreted to be deposits in fluvial to near-shore environments possibly as the downstream evolution of alluvial fan environments (FA1 and FA2).

Description: in the south of Longue Island (see location Fig.4), a 30 m-thick succession of very coarse to medium-grained cross-bedded sandstones, typically organized into sigmoidal megaripples, is exposed (Fig. 9A and 9D). These decimeter-thick sigmoidal bedsets extend over 2 to $5 \mathrm{~m}$ and show a $15^{\circ}$ to $30^{\circ}$ inclination of individual sets. Measurements of oblique set apparent dips reveal a main SE oriented progradation with subordinate orientations toward the W, NE, and E (Fig.18). Sigmoidal lamina sets can be locally erosional and commonly show cyclic increases and decreases in thickness within the same bed. Mud drapes, mud clasts, opposite ripples and bioturbation are present even though relatively scarce, possibly due an overall low fraction of mud-sized sediments. However, opposite megaripples (i.e. herring-bones) occur (Fig. 9B). In places, small-scale trough-cross ripple laminations are observed between bedsets. Frequent gravel lags and centimeter to decameter scale isolated lenses of well-rounded ultramafic pebbles within a calcareous muddy matrix are observed (Fig. 9C). These sandstones are primarily made of altered serpentinite grains and ferricrete fragments. Grains are coated with a fringing marine cement and separated from each other by drusy calcite cements (Fig. 9E). 
Interpretation: The common preservation of alternating thicker and thinner sigmoidal foresets, erosional (reactivation) bounding surfaces, together with herring-bone cross-bedding, strongly suggests a tidal influence (spring-neap tide bundling). In addition, the apparent lack of storm and wave-related sedimentary features (ie. HCS, SCS, oscillating ripple laminations) point to the fact that the depositional environment is not significantly influenced by oscillating currents. The weak preservation of mud drapes and the lack of bioturbation could be seen as evidencing rapid bedform deposition by sustained, high-energy currents that reworked evidence for depositional pauses (eg. Willis et al., 1999). Consequently, cross-bedded sandstones are therefore thought to correspond to tidally influenced shallow marine sandstones, possibly conforming to tidal sand bars in an estuarine environment (Belderson et al., 1982; Reynaud \& Dalrymple, 2012; Snedden \& Dalrymple, 1999; Snedden, et al., 1999), or, alternatively, to distributary mouth bars in a tideinfluenced delta front.

Description : in the west of the Pindaï Peninsula, at the nautical base outcrops, as well as on the Didot Islet and the Beco Peninsula (see location Fig.4), fine to very fine-grained, tabular crossbedded, typically bioturbated sandstones are exposed (Fig. 10A and 10D). The direction of apparent progradation is dominantly towards the SSW, yet a few measurements were found to be towards the E and NE (Fig. 14). Where grain size is finer, cross bedding is replaced by parallel laminations and isolated unidirectional ripples (Fig. 10B). Bioturbation is also more pronounced and trace fossils are more identifiable. Burrows include Thalassinoides and Dactyloidites (Fig. 10C). Additionally, numerous mafic and ultramafic granules are present, typically as lags or within burrow infills. In S2 well, cross-bedded and bioturbated sandstones exhibit a scarce and poorly diversified foraminiferal association dominated by poorly preserved Miogypsina and Sorites. 
Interpretation: these sandstone facies are interpreted as sandy subtidal deposits downslope of FA-4 tidal sands. Their finer grain size, the ichnofacies (Thalassinoides-Dactyloidites) and the lack of evidence for clear tidal features is consistent with deposition below the low tide limit. In addition, while Thalassinoides burrows may characterize diverse depositional settings from shallow to deep water environments (Bromley, 1996), Dactyloidites is usually considered to be restricted to sandy substrate in very shallow, shoreface environments (Uchman \& Perversler, 2007). Finally, the scarcity and poor preservation of benthic foraminifers suggest these are not in situ but likely derived from neighboring euphotic to upper mesophotic environments (e.g. Hallock \& Glenn, 1986; Pomar et al., 2014).

\section{FA6- Subtidal, seagrass-related, low-angle carbonate ramp (Fig. 11)}

Description: outcrops from the B3 Népü Limestone Member are dominated by massive and chalky carbonates, which are commonly interbedded with centimeter to meter-thick intervals of ultramafic cobbles and boulders (Fig. 11D). Three dominant carbonate depositional facies have been identified within the FA-6 facies association: 1) FA6-1: Foraminiferal-coralline algal packstone-grainstones (Facies FB2 in Maurizot et al., 2016), 2) FA6-2: Scleractinian floatstone with a foraminiferal-coralline algal packstone-grainstone matrix (Facies FB1 in Maurizot et al., 2016), and 3) FA6-3: Scleractinian boundstones.

Foraminiferal-coralline algal packstone-grainstones (FA6-1) are organized into decimeter to meter-thick beds (Fig. 11B). They are dominated by benthic foraminifera and coralline algae, and include small proportions of mollusks and echinoderm fragments. Scleractinians may be present as sparse gravel to cobble-sized coral fragments but do not contribute significantly to the sand-sized skeletal fraction. It is likely that part of the sandy fraction deriving from corals is present as dissolved grains and has therefore been counted as indeterminate elements $(<7 \%)$. Vertical calcitic tubes of shipworm (teredinid) bivalves, 1 to $2 \mathrm{~cm}$ in diameter and 10 to $30 \mathrm{~cm}$ in length, may be common in a few beds (Fig. 11C). Packstones and grainstones exhibit very similar biological composition (Tables 1 and 2, Fig. 12) with high proportions of benthic foraminifers 
(52\% and $46 \%$ respectively), articulated coralline algae (13\% and $16 \%$ ) and encrusting coralline algae (17\% and $25 \%)$. In both textures, the foraminiferal assemblage is dominated by benthic foraminifers which are known as common epiphytes (e.g. Chaproniere, 1975; Hallock et al., 2006; Pomar et al., 2014; Reich et al., 2014) such as the miliolid Austrotrillina, soritids (Fig. 13A, B, C, F), peneroplids, and calcarinids (Neorotalia) (Fig. 13D), which represent, in average, $30 \%$ (packstones) and $27 \%$ (grainstones) of the sand-sized bioclastic grains. Victoriellid encrusting foraminifers (Fig. 13E) are common (7\% in average but may reach up to $47 \%$ of the sand-grained bioclastic fraction). They are always found isolated thus suggesting an unpreserved substrate of possible phytal origin. The alveolinid Flosculinella (Fig. 13C) is present in a few samples. Gypsina (Fig. 13E) is of common occurrence as well as other robust hyaline foraminifers such as amphisteginids and miogypsinids. Based on the nature of epiphytic (Austrotrillina, soritids, peneroplids and calcarinids) and potentially epiphytic (victoriellids) taxa which largely dominate the foraminiferal assemblage, three foraminiferal associations have been defined (Figs.12 and 14): 1) a porcelaneous-dominated epiphytic foraminiferal association dominated by Austrotrillina, soritids and peneroplids $77 \%$ in average of the epiphytic foraminiferal composition, $45 \%$ of the whole foraminiferal content) (Fig. 13A, B, C, F), 2) a rotalid-dominated epiphytic foraminiferal association dominated by Neorotalia ( $88 \%$ in average of the epiphytic foraminiferal composition, $57 \%$ of the whole foraminiferal content) (Fig. 13D) and 3) a victoriellid-dominated association (60\% of the whole foraminiferal content) (Fig. 13E). The coralline algal assemblage is composed of Lithophyllum gr. pustulatum, "Lithophyllum pseudoamphiroa", Corallina and Jania. The green algae Halimeda is rare and has been observed in a very few samples (Fig. 13B). Sand-grained to gravel-grained lithoclasts (altered peridotites) mixed within the carbonate fraction are of common occurrence (Fig. 13B). Scleractinian floatstones (FA6-2) are commonly interbedded within foraminiferal-coralline algal packstone-grainstones and conglomerate thin (0.10-1.0 meter-thick) beds (Fig. 11D). The foraminiferal assemblage is similar to that of the foraminiferal-coralline algal packstonegrainstones (Table 1) since it is dominated by benthic foraminifers with a large proportion of 
epiphytes and coralline algae including both articulated and encrusting forms. The benthic foraminiferal association is composed of soritids, alveolinids (Flosculinella), miliolids (Austrotrillina), calcarinids (Neorotalia) together with significant proportions of victoriellids. amphisteginids, calcarinids and miogypsinids (Miogypsina and Miogypsinoides) are present in minor proportions. The scleractinian assemblage includes Heliastrea, Stylophora, Goniopora, Porites, Siderastrea and Dipastraea (Maurizot et al., 2016). Corals are mainly found as rubbles but rare in-situ, small-sized $(<50 \mathrm{~cm}$ thick, $<1 \mathrm{~m}$ in diameter $)$ coral bioconstructions $(=$ scleractinian boundstone: FA6-3) have been observed interbedded within coral floatstone intervals (Fig. 11G).

A few kilometers away from the Wharf outcrops, at the S2 well, the B3 Member is significantly thicker (80 m), strongly dolomitized (Fig 11E), and displays karst features filled by reddish clayrich sediments (Fig 11F).

Interpretation: in both foraminiferal-coralline algal packstone-grainstones and coral floatstones, the foraminiferal assemblage is dominated by taxa which are known as common epiphytes (flat, disk-shaped soritids, Austrotrillina, Neorotalia) and which suggests very shallow, euphotic environments with extensive development of seagrass meadows (e.g. Chaproniere, 1975; Pomar et al., 2014). Robust and rounded specimens of amphisteginids are also indicative of very shallow-water settings (Hallock \& Glenn, 1986) and their diameter-thickness ratios $(<2)$ suggest water-depth lower than 10 meters (Renema, 2005; Mateu-Vicens et al., 2009). Even though calcarinids such as Neorotalia may live on sandy substrates, they have been shown to prefer phytal substrate such as macro-algae (Renema, 2010; Reich et al., 2015), short filamentous algae (Renema, 2003) and seagrasses (Lobegeier, 2002). Neorotalia has been shown to be abundant in Oligo-Miocene seagrass facies (Fournier et al., 2004; Pomar et al., 2014). The FlosculinellaAustrotrillina-soritid association has been reported in various Neogene seagrass meadows environments (Chaproniere, 1975; Fournier et al., 2004; Hallock et al., 2006; Reich et al., 2014). Additionally, the general absence of preserved substrate suggests that victoriellids encrusted 
441

non-calcified biota such as, possibly, seagrass leaves or rhizomes. The relatively high-mud content (packstone texture: Fig. 13A, B, C, D, E) also supports the interpretation of sea-grass environments (e.g. Brandano et al., 2009; Reuter et al., 2012; Mateu-Vicens et al., 2012). Additionally, abundance of articulated coralline algae is a common feature of seagrass meadow environments (e.g. Lukasik et al., 2000; James \& Bone, 2007) even though they may be common in a wide range of shallow marine environments. Similar bioclastic composition present in grainstones which may reflect a deposition in high-energy, non- or poorly-vegetated areas, at vicinity of seagrass meadows.

The foraminiferal assemblage of the scleractinian floatstones suggests that coral fragments probably came from nearby inner-shelf patch reef frameworks or could represent sparse coral colonies within seagrass meadows. The few in situ coral bioconstructions observed in the B3 Népü Limestone Member suggest that they were probably relatively sparse on sea bottom of relatively small dimensions (meter-scale).

As a consequence, the biotic composition and the textural characters of the FA6 facies association suggest a deposition within the euphotic zone, in a relatively high energy environment which is extensively vegetated by seagrass meadows and colonized by sparse and small-sized coral bioconstructions. Additionally, the sub-rounded pebble lags which are interbedded within carbonate deposits are an additional evidence for the proximity of the ultramafic source in this mixed system and likely represent the reworking of fluvial outputs by waves and marine currents (Nemec \& Steel, 1984).

\section{FA7- Subaqueous distributary channel fills (Fig. 15)}

Description: in the proximal part of the B3 Népü Limestone Member, numerous conglomeratic channel-fills occur. They are particularly well-exposed on the Pindaï Peninsula, at the 
southeastern extremity of the Wharf outcrops (Fig. 15A), and to the South of the Baie des Sapins (Fig. 15C). They cut into shallow water limestones and are 2 to 5 meters-thick and 15 to 30 meters-wide. At the Wharf outcrops, they are stacked into amalgamated channel complexes (Fig. 15A). Individual channel fills comprise well rounded, ultramafic pebbles-cobbles in a calcareous matrix and coarse-grained gravelly sandstones (Fig. 15B). The composite infill is organized into a fining upward, laterally accreting stack of inclined bedsets.

Interpretation: the interfingering of conglomerate and carbonate ramp deposits, the sharp nature of erosional surfaces and the normally graded infills strongly suggest that these conglomerates deposited in subaqueous distributary channels which formed in an alluvial-fan front setting, by erosional currents transporting material from the Kopéto and Boulinda massifs into a shallow-water carbonate inner ramp (e.g. Nemec \& Steel, 1984). The lack of bidirectional current structure would rule out a tidal origin for such channels. Such channels can be regarded as the main feeders of the coarse terrigenous fraction present within the FA6 carbonate deposits (conglomeratic lags).

Description: at the Wharf outcrops and the Grimault Islet (see location Fig. 4), the base of the B3 Népü Limestone Member is marked by an alternation of marls and centimeter-thick beds of very fine-grained sandy to silty limestones with plant debris (Fig. 16A). Some of these silty marls intervals are entirely cut by vertical pneumatophore roots (Fig. 16C). Among such alternations, lithoclastic wackestone to packstone beds with fragments of echinoids and gastropods are observed. In addition, several thin layers with decimeter-scale well rounded and well sorted ultramafic pebbles in a calcareous muddy matrix are also identified (Fig. 16D). Finally, sandy intervals display large scale sigmoidal dunes prograding towards the SSW to SSE. Foresets have a $5^{\circ}$ to $15^{\circ}$ dip and bedforms extend over at least several tens of meters. These deposits consist 
493 in medium-grained sandstones with floating granules, common bioturbation and erosional 494 topsets (Fig. 16B).

495

496 Interpretation: the alternation between marls and fine-grained sandstones with vegetal debris 497 and pneumatophore roots is seen as characteristic of a supratidal to intertidal environment 498 (Shinn, 1983). Pneumatophore roots are highly likely to evidence a supratidal swamp in a 499 tropical climate. Sigmoidal dunes are consistent with this interpretation and root traces and leaf 500 fragments suggest that they formed in a supra to intertidal environment such as tidal sand bars. 501 Conglomerates, in turn, would correspond to the terminal distributary channels of the alluvial502 fan system.

503

504 
506 The contact between the Aquitanian Lower Nepoui Formation and Burdigalian Upper Nepoui

507 Formation is not observable at Chapeau Chinois outcrop (Fig.7 in Maurizot et al., 2016), but the 508 transition is continuously recorded at well S2 (Fig. 17A). This transition, between $-104 \mathrm{~m}$ and $509-98 \mathrm{~m}$, shows the top of Lower Népoui Formation (Aquitanian after Maurizot et al., (2016)), 510 which is characterized by scleratinian floastones with a foraminiferal-algal packstone matrix. 511 The uppermost Lower Népoui limestones display in that location a rich foraminiferal 512 assemblage characterized by a regular occurrence of Miogypsina, Heterostegina, Lepidocyclina, 513 Sorites, Neorotalia, Cibicides, Elphidium and discorbids (Fig. 17B). The mixture of epiphytic 514 foraminifers such as Sorites, Neorotalia, Cibicides, Elphidium, discorbids and larger foraminifers such as Miogypsina, Lepidocyclina and Heterostegina within the underlying limestones are indicative of a euphotic to upper mesophotic depositional environment for the uppermost Lower Népoui Formation (Pomar et al., 2014).

Between $-98 m$ to $-92 \mathrm{~m}$ depth, the transition from the Lower Népoui limestones to the Upper Népoui basal sandstones is gradational, with a progressive increase in terrigenous clasts and a decrease in biogenic components (Fig. 17C). At the top of this interval, fine to mediumgrained clean sandstones (FA4-FA5 facies associations) display parallel to cross laminations with common bioturbation. A coarsening upward trend is evidenced between $-92 \mathrm{~m}$ to $-83 \mathrm{~m}$, with coarse- to medium-grained cross-bedded sandstones at the top. Constitutive elements primarily comprise weathered serpentinite grains as well ferricrete clasts. Additionally, the sandstones from the entire terrigenous interval $(-98 \mathrm{~m}--83 \mathrm{~m})$ are strongly bioturbated and contain a low-diversified foraminiferal assemblage (mainly broken and likely transported Miogypsina and Sorites). The clean nature of the sand, the occurrence of cross-bedded beds and the associated ichnofacies (Thalassinoides-Dactyloidites) suggest a deposition in a shallow, subtidal, high-energy environment. 
532

533

karst features infilled with reddish clay-rich sediment. Such reddish infills likely correspond to reworked laterites of the post-Burdigalian Muéo Formation that unconformably overlay the Miocene series (Coudray, 1975; Paris, 1981; Sevin et al., 2014).

The significant dolomitization of this interval could be explained by the high Mg content of runoff water derived from weathered peridotite massifs in an area where mixing fresh and marine water are already prone to induce secondary dolomitization (Tucker and Wright, 1990).

Finally, both the uppermost Lower Népoui and lowermost Upper Népoui formation were deposited in shallow waters, within the euphotic to upper mesophotic environments. As a consequence the upward transition from a carbonate-dominated to a siliciclastic-dominated system is not accompanied by a major shift in paleowater depth.

\section{DISCUSSION}

\subsection{Revised depositional model for the Burdigalian Upper Népoui} mixed system

This study proposes a revised depositional model of the Burdigalian Upper Népoui formation. This constrained by seven synthetic logs, from S2 core data and 6 key outcrop sections (Fig. 18), which capture the architecture of this mixed carbonate-siliciclastic system and its evolution through time (Fig. 19).

Facies analysis and correlation of synthetic cross-sections suggest that alluvial fan and fluvial deposits (FA1, FA2 and FA3) evolve distally into tidally influenced nearshore sandstone deposits (FA4 and FA5) in only a few kilometers, in the lower part of the Upper Népoui formation (Fig. 18). Alluvial deposits are of restricted extension and the relatively sharp transition to marine deposits together with the lack of preserved floodplain deposits strongly suggest a fan delta depositional system (sensu Holmes, 1965). The good preservation of tidal deposits could also be 
558

559

560

561

562

563

564

565

566

567

568

569

570

571

572

573

574

575

576

577

578

579

580

581

582

583

584

consistent with sedimentation occurring within a paleovalley (estuarine environment) or a lagoonal embayment (Dalrymple et al., 1992). However, the lateral continuity of facies associations along a $10 \mathrm{~km}$-long transect (perpendicularly to a proximal-distal axis), between the Pindaï peninsula and the Beco Island (Fig. 18), favors a fan delta system developing on an unconfined continental shelf. During this stage, continental alluvial fan deposits (FA1, FA2 and FA3) would evolve laterally into a relatively wide and low-angle shelf (up to $5 \mathrm{~km}$ ) where intertidal (FA4) and subtidal (FA5) terrigenous sedimentation occurs (Fig. 19A). In the S2 well, a relatively thin $(<20 \mathrm{~m})$ siliciclastic unit, composed of facies associations FA5 and FA4 progressively changes upward into carbonate ramp deposits (FA6). This transitional facies change suggests coeval terrigenous inputs and carbonate ramp sedimentation. Lateral transition between shallow-water carbonates and siliciclastic deposits is observed in the modern lagoon of New Caledonia where high fluvial discharges from peridotite massif watersheds (Garcin et al., 2013) are coeval with high carbonate productivity (Chevillon, 1992; Cabioch et al., 2008; Le Roy et al., 2019). Carbonate sedimentation in the B3 member is dominated by seagrass-related carbonate production (FA6), suggesting that the subtidal, euphotic shelf was extensively covered by seagrass meadows. In Pindaï and Grimault sections the upward vertical transition from terrigenous-dominated to carbonate-dominated sedimentation is characterized by the development of a carbonate-dominated unit deposited in tidal-flat and swamp environments (FA8). This suggests that tidal currents were able to import toward coastal environments (tidal flat and swamps) significant volume of carbonate sediment produced in subtidal seagrass environments. The interfingering of conglomerate-filled channels (FA7) within FA6 and FA8 carbonate deposits indicate that the coarse terrigenous fraction of the sediment was supplied by the alluvial fan through distributary channels cross-cutting the tidal flat and the subtidal seagrass meadows (Fig.19B). Similar conglomerate-filled feeder channels developing at the mouth of river courses and cross-cutting shallow-water mixed carbonate-siliciclastic deposits have been evidenced at the front of a Tortonian fan delta from the Vera Basin, Spain (Braga et al., 2001). These channels, which are not related to relative sea level falls and emersion of the shelf 
585

586

587

588

589

590

591

592

593

594

595

596

597

598

599

600

601

602

603

604

605

606

607

608

609

610

611

(i.e. incised valley fills), have been shown to feed turbidite lobes in the basin. Similarly, in the Burdigalian Upper Népoui formation, conglomerate-filled channels cross-cutting seagrass deposits (FA8) are subquaeous and developed during an overall transgressive trend. As a consequence, the vertical and lateral evolution of facies within the Burdigalian Upper Népoui formation requires the definition of two distinct depositional models for the mixed carbonatesiliciclastic system: 1) a siliciclastic-dominated system, during relative sea level lowstand and/or early transgression, characterized by an extensive terrigenous intertidal and subtidal domain and by moderate seagrass carbonate production (Fig. 19A), 2) a carbonate-dominated ramp system, during later transgression and possibly relative sea level highstand, typified by extensive seagrass meadow development over the entire subtidal, euphotic domain (Fig. 19B). Distal equivalents in mesophotic to oligophotic environments are not observed in the current dataset.

\subsection{Factors controlling the depositional architecture of the Upper}

\section{Népoui Formation}

The depositional environments recorded by the Burdigalian deposits of Népoui suggest significant creation of accommodation space as well as in situ changes of environmental conditions. During the Burdigalian, the onset of siliciclastic sediment deposition (B1 Pindaï Conglomerates and B2 Wharf Members) overlying the Aquitanian ramp is recorded in the S2 well by a progressive shift towards sandy terrigenous deposits with an upward decrease in carbonate components (Fig. 17). This transition marks the demise of the Aquitanian carbonate ramp, most likely due to a significant increase in water turbidity associated with the progradation of alluvial fans. This facies shift has been formerly interpreted by Maurizot et al. (2016) as resulting from a major forced regression driven by a tectonic uplift. However, the lack of subaerial exposure evidence and the lack of significant paleobathymetric gap between the top Aquitanian limestones (euphotic environment: 0-20m) and the base Burdigalian tidal sands in 
S2 well do not support this interpretation of a forced regression at the Lower Népoui-Upper Népoui transition. The increase of detrital fluxes and transient decrease or demise of carbonate production during the Burdigalian in the Népoui area may result from other parameters such as: 1) an intensification of erosional and/or weathering processes on peridotite massifs due to climate changes or to gravitational collapses linked with the fault network structuring Grande Terre (Iseppi et al., 2018), or 2) an autocyclic lateral migration of a pre-existing alluvial fan system. The overall transgressive trend recorded in the Pindaï Peninsula by the upward succession from fluvial to intertidal and finally subtidal carbonate ramp deposits suggests that the Upper Népoui formation developed during a period of increasing accommodation space. Published eustatic curves indicate an overall increase of eustatic sea level up to 80 meters during the Burdigalian (Haq et al., 1987; Miller et al., 2005). Hence, eustatic variations may have largely controlled the creation of accommodation space which allowed the accumulation of 60 meters (outcrops of Pindaï Peninsula) to 100 meters (S2 well) of alluvial to shallow-water (shoreface sands and euphotic seagrass carbonates) deposits. This creation of accommodation space may also be linked to the collapse of the western margin driven by the post-obduction isostasic rebound of Grande Terre (Lagabrielle \& Chauvet, 2008, Collot et al., 2017).

\subsection{Seagrass and patch-reef carbonate production in high-terrigenous}

\section{influx settings}

A variety of carbonate-producing biota, including some large benthic foraminifera, coralline algae, echinoderms, molluscs, and corals, tolerate nearly continuous siliciclastic influx (e.g. Wilson, 2005; Novak et al., 2013; Santodomingo et al., 2015). The most distinctive character of the lower Miocene carbonate sedimentation of the Népoui system is the dominance of seagrass associated production, with also common occurrence of coral bioconstructions (meter-scale patches). Seagrass-related carbonate production has been shown to be highly tolerant to high terrigenous fluxes in various Cenozoic carbonate systems (e.g. Beavington-Penney et al., 2004; 
Reuter et al., 2012; Brandano and Ronca, 2014; Tomas et al., 2016). In such settings, variations in terrigenous supplies modify the taxonomic composition of plant assemblages on sea bottom and therefore the morphology of phytal substrates for epiphytic foraminifers. In modern environments, the nature and composition of epiphytic communities have been shown to depend on the species of the seagrass substrate (e.g. Beavington-Penney et al., 2004; Perry et al., 2012) or more commonly to the nature of the phytal substrate (seagrass vs macro-algae: Fujita \& Hallock, 1999 ; Benedetti \& Frezza, 2016). Morphotypes of epiphytic foraminifers have been revealed to be useful to analyze the assemblage structure and provide criteria to infer different types of phytal substrates (Langer, 1993; Mateu-Vicens et al., 2010; 2014). Seagrasses are typically dominated by flat, discoidal foraminiferal morphotypes (A and SB morphotypes after Langer's (1993) classification, modified by Mateu-Vicens et al., 2014) since these foraminifers have long life cycles (at least one year) and require long lasting and flat substrates. In contrast, macroalgae, whose life span is shorter, are the substrate of smaller and robust foraminifers (morphotypes B and D) with shorter life cycles (Mateu-Vicens et al., 2010). The porcelaneousdominated epiphytic association from Népoui is largely composed of SB morphotypes (flat and discoidals soritids, peneroplids) and likely reflects a dominant seagrass substrate. In contrast, the abundance of Neorotalia (morphotype B) in the calcarinid-dominated association would characterize environments significantly colonized by macroalgae.

Repeated changes in epiphytic foraminiferal associations (porcelaneous-dominated vs calcarinid (Neorotalia)-dominated) within the Népü limestone may therefore reflect changes through time and space of the nature of the phytal substrate which in turn can reflect variations in some environmental parameters such as turbidity or salinity. In modern tropical carbonate environments, the dominance of calcarinids has been shown to be related to the extensive development of macro-algae (Renema, 2010).

The Miocene seagrass skeletal association from Népoui is characterized by a high foraminiferal ( $52 \%$ of the sand-grained skeletal fraction in average) and coralline algal content (33\%), and an extreme scarcity of Halimeda green algae. Such a bioclastic composition is consistent with the RA 
666

667

668

(red-algal) foralgal seagrass assemblage (Brandano et al., 2019), which characterizes high density tropical to subtropical seagrass meadows. RA-foralgal seagrass-related association is reported from modern Mediterranean environments (Brandano et al., 2019) as well as from a variety of ancient tropical carbonate systems (e.g. Seeb Formation, Eocene, Oman: BeavingtonPenney et al., 2004; Malampaya buildup, Philippines, Chattian to Burdigalian: Fournier et al., 2004, SE Spain, Messinian: Sola et al., 2013). In densely vegetated areas, particularly in the case of long-leaved seagrasses, oligophotic conditions prevail at sea bottom thus impeding the development of green algae and promoting in contrast coralline algae, which are known to be highly tolerant to low-light, oligo-mesotrophic conditions. Such an interpretation may explain the high coralline content and the scarcity of Halimeda of seagrass sediments in the Népoui seagrass-related sediment, but the oligophotic conditions at sea bottom can also result of relatively high-turbidity created by strong terrigenous discharges. As a consequence it can be suggested that in high-terrigenous settings, RA-foralgal associations may also occur in low to moderately dense seagrasses as a result of water turbidity.

Seagrass meadows have a significant effect on current velocity reduction, sediment trapping and decreasing resuspension of particles thus leading to a reduction of the turbidity in the water column (de Boer, 2007). The reduction of fine particle resuspension within seagrass meadows may have drastically limited the negative effect of water turbidity for the development of lightdependent biota such as symbiont-bearing foraminifers, coralline algae and corals.

Differential trapping of sediments within the seagrass meadow may lead to slightly raised sea bottom in vegetated areas (e.g. Pérès \& Picard, 1964; Madsen et al., 2001; Fujita et al. 2015). Water flow and terrigenous influx are therefore likely to be directed toward the lower lying areas, thus reducing the risk of suffocation for filter-feeding biota living in the seagrass meadow. The coeval development of seagrass meadows and terrigenous sediment flows on the alluvialfan front possibly also controls the aggrading nature (vertical stack) of the main distributary channel infills (Fig 15). 
692 Additionally, scleractinian bioconstructions that form in turbid water under significant 693 terrigenous inputs, are common in the geological record (e.g. Sanders \& Baron-Szabo, 2005) and 694 particularly in Cenozoic shallow-water sedimentary systems from the Indo-Pacific (e.g. Wilson, 695 2005; Novak et al., 2013; Santodomingo et al., 2015) and Mediterranean regions (Galloni et al., 696 2001; Brandano et al., 2010, 2016; Mazzucchi \&Tomassetti, 2011). This is consistent with the 697 common occurrence of coral fragments and in situ bioconstructions within the Lower and Upper 698 Népoui limestones. As evidenced from Miocene patch-reefs formed at the seaward margin of the 699 equatorial Mahakam Delta (Wilson, 2005), carbonate production and patch-reef development 700 may occur in turbid-water, delta-front areas during any phase of eustatic sea level.

701 The relative tolerance of seagrass ecosystems as well as small-scale coral patches environments 702 to high terrigenous influx may explain the significant development of ramp carbonate systems 703 with mixed foraminiferal and scleractinian production at the mouth of alluvial fan systems, in 704 tropical settings.

705 


\section{CONCLUSION}

The Burdigalian carbonate ramp system of Népoui is a well-constrained example of seagrassdominated and coral-bearing carbonate systems developing in high terrigenous influx setting

711 and tropical climate.

712 (1) During the Burdigalian, the upward succession from the Pindaï conglomerate to the Népü Limestone member is the result of the retrogradation or lateral migration of a fan delta system passing laterally into a carbonate ramp, during a marine transgression. Despite this transgressive trend, the carbonate ramp received high-terrigenous influx as evidenced by smallscale conglomeratic channels that randomly incised the carbonate ramp.

(2) Post-obduction isostatic rebound resulted in an extensional tectonic regime and margin collapse that possibly favored the onset and preservation of terrigenous fan delta and carbonate ramp systems.

(3) Extensive development of seagrass meadows and potentially of macro-algae occurred in shallow, euphotic environments subject to high-terrigenous discharge. Phytal substrates induced by seagrass vs macro-algae colonization of sea bottom strongly controlled the nature of carbonate production and promoted the accumulation of foraminiferal-coralline algal sediments. (4) Finally, the development of seagrass meadows has probably largely contributed to the preservation of a diverse and significant carbonate production in a context of strong terrigenous inputs, by reducing water turbidity and by limiting the risk of suffocation for filter-feeding biota. The lateral and vertical variability of the Burdigalian carbonate ramp improves knowledge on the heterogeneity of potential hydrocarbon reservoirs in mixed carbonate-siliciclastic systems.

\section{ACKNOWLEDGEMENTS}

This work was funded jointly by the Adecal Technopole and the Geological Survey of New Caledonia (SGNC) of the Department of Industry, Mines and Energy of New Caledonia (DIMENC). 
733 We thank the Institute of Research for the Development (IRD) for the provision of core drilling

734 material and the "Diodon" boat to access the islets. Special thanks to Mathieu Mengin (SGNC) and 735 John Butcher (IRD) who conducted the core drilling work and Boris Marcaillou (GeoAzur), 736 Samuel Tereua (IRD) and Miguel Clarque (IRD) for the boat travels to the islets that were 737 sometimes difficult to approach.

738

739 
Aitchison, J. C., G. L. Clarke, S. Meffre, and D. Cluzel (1995), Eocene arc-continent collision in New Caledonia and implications for regional Southwest Pacific tectonic evolution, Geology, 23(2), p. 161-164.

744

Allen, J. R. L., (1963), The classification of cross-stratified units with notes on their origin: Sedimentology, v. 2, no. 2, p. 93-114.

Allen, J. R. L., (1983), Studies in fluviatile sedimentation: Bars, bar-complexes and sandstone sheets (low-sinuosity braided streams) in the brownstones (L. devonian), welsh borders, Sedimentary Geology, v. 33, no. 4, p. 237-293.

Bassant, P., Van Buchem, F.S.P., Strasser, A., Görür, N. (2005), The stratigraphic architecture and evolution of the Burdigalian carbonate-siliciclastic sedimentary systems of the Mut Basin, Turkey. Sedimentary Geol,ogy , v. 173, 187-232.

755

756

757

758

759

760

761

762

763

764

765

766

767

768

769

770

771

772

773

774

775

776

777

778

779

780

781

782

783

784

785

786

787

788

789

790

791

Bassi, D. Nebelsick, J., (2010). Components, facies and ramps: redefining Upper Oligocene shallow water carbonates using coralline red algae and larger foraminifera (Venetian area, northeast Italy). Palaeogeography, Palaeoclimatology, Palaeoecology, v. 295, 258-280.

Beavington-Penney, S.J., Wright, V.P., Woelkerling, W.J., (2004), Recognising macrophyte vegetated environments in the rock record: a new criterion using 'hooked' forms of crustose coralline red algae. Sedimentary Geology, v. 166, p.1-9.

Belderson, R., Johnson, M., and Kenyon, N., (1982), Bedforms, in Stride, A.H (ed.), Offshore tidal sands, processes and deposits, Chapman and Hall., pp.27-57.

Belperio, A. P. (1983). Terrigenous sedimentation in the central Great Barrier Reef lagoon: a model from the Burdekin region. BMR Journal of Australian Geology and Geophysics, 8, no. 3, p.179-190.

Benedetti, A, Frezza, V. (2016) Benthic foraminiferal assemblages from shallow?water environments of northeastern Sardinia (Italy, Mediterranean Sea). Facies, 62:14.

Blair, T. C., (1999), Cause of dominance by sheetflood vs. debris-flow processes on two adjoining alluvial fans, Death Valley, California, Sedimentology, v. 46, no. 6, p. 1015-1028.

Blair, T. C., and McPherson, J. G., (1994), Alluvial fans and their natural distinction from rivers based on morphology, hydraulic processes, sedimentary processes, and facies assemblages, Journal of Sedimentary Research, v. 64, no. 3a, p. 450-489.

Bluck, B. J., (1979), Structure of coarse grained braided stream alluvium, Earth and Environmental Science Transactions of the Royal Society of Edinburgh, v. 70, no. 10-12, p. 181221.

Braga, J.-C, Martín, J.M., Wood, J.L., (2001), Submarine lobes and feeder channels of redeposited, temperate carbonate andmixed siliciclastic-carbonate platform deposits (Vera Basin, Almería, southern Spain). Sedimentology, v. 48, p. 99-116.

Brandano, M., Frezza, V., Tomassetti, L., Pedley, M., Matteucci, R., (2009). Facies analysis and palaeoenvironmental interpretation of the Late Oligocene Attard Member (Lower Coralline Limestone Formation), Malta. Sedimentology, v. 56, no. 4, p. 1138-1158. 
792

793

794

795

796

797

798

799

800

801

802

803

804

805

806

807

808

809

810

811

812

813

814

815

816

817

818

819

820

821

822

823

824

825

826

827

828

829

830

831

832

833

834

835

836

837

838

839

840

841

842

843

844

Brandano M., Frezza V., Tomassetti L., Bosselini F. \& Mazzucchi A. (2010): Depositional model and paleodepth reconstruction of a coral-rich, mixed carbonate-siliciclastic system: the Burdigalian of Capo Testa (northern Sardinia, Italy). Facies, v. 56, p. 433-444.

Brandano, M., Ronca, S., (2014). Depositional processes of the mixed carbonatesiliciclasticrhodolith beds of the Miocene Saint-Florent Basin, northern Corsica. Facies, v. 60, 7390.

Brandano M., Tomassetti, L., Frezza V., (2015). Halimeda dominance in the coastal wedge of Pietra di Finale (Ligurian Alps, Italy): The role of trophic conditions. Sedimentary Geology, v. 320, 30-37.

Brandano, M., Bosellini, F.R., Mazzucchi, A., Tomassetti, L., (2016). Coral assemblages and bioconstructions adapted to the depositional dynamics of a mixed carbonate siliciclastic setting: the case study of the Burdigalian Bonifacio Basin (South Corsica). Rivista Italiana di Paleontologia e Stratigrafia, v. 122, 37-52.

Brandano, M., Tomassetti, L. Mateu Vicens, G., Gaglianone, G., (2019). The seagrass skeletal assemblage from modern to fossil and from tropical to temperate: Insight from Maldivian and Mediterranean examples. Sedimentology, v. 66, p. 2268-2296.

Cabioch, G., Correge, T., Turpin, L., Castellaro, C., and Recy, J., (1999), Development patterns of fringing and barrier reefs in New Caledonia (southwest Pacific), Oceanologica acta, v. 22, no. 6,p. 567-578.

Cabioch, G., Montaggioni, L., Thouveny, N., Frank, N., Sato, T., Chazottes, V., Dalamasso, H., Payri, C., Pichon, M. and Sémah, A.-M. (2008) The chronology and structure of the western New Caledonian barrier reef tracts. Palaeogeography, Palaeoclimatology, Palaeoecology, v. 268, p.91-105.

Cabioch, G., Recy, J., Jouannic, C., and Turpin, L., (1996). Contrôle climatique et tectonique de l'édification récifale en Nouvelle-Calédonie au cours du Quaternaire terminal, Bulletin de la Société Géologique de France, v. 167, no. 6, p. 729-742.

Catuneanu, 0., (2019). Model-independent sequence stratigraphy . Earth-Science Reviews, 188, p. 312-88.

Chaproniere, G.C.H., (1975). Palaeoecology of Oligo-Miocene Foraminifera, Australia. Alcheringa 11, p. 37-58.

Chevillon, C., (1992). Biosédimentologie du grand lagon nord de la Nouvelle-Calédonie, ORSTOM, Aix-Marseille II, 224 p.

Cluzel, D., (1998). Le Flysch post-obduction de Népoui, un bassin transporté ? Conséquences sur l'âge et les modalités de l'obduction tertiaire en Nouvelle-Calédonie (Pacifique sud-ouest). Comptes Rendus de l'Académie des Sciences - Series IIA - Earth and Planetary Science, v. 327, no. 6, p. 419-424.

Cluzel, D., J. Aitchison, G. Clarke, S. Meffre, and C. Picard (1994), Point de vue sur l'évolution tectonique et géodynamique de la Nouvelle-Calédonie (Pacifique, France), Comptes Rendus de l'Académie des Sciences, Série 2, 319(6), p. 683-690. 
845

846

847

848

849

850

851

852

853

854

855

856

857

858

859

860

861

862

863

864

865

866

867

868

869

870

871

872

873

874

875

876

877

878

879

880

881

882

883

884

885

886

887

888

889

890

891

892

893

894

895

896

897

898

Cluzel, D., J. C. Aitchison, and C. Picard (2001), Tectonic accretion and underplating of mafic terranes in the late Eocene intraoceanic fore-arc of New Caledonia (Southwest Pacific): geodynamic implications, Tectonophysics, 340(1/2), p. 23-59.

Cluzel, D., Bosch, D., Paquette, J. L., Lemennicier, Y., Montjoie, P., and Ménot, R. P., (2005). Late Oligocene post-obduction granitoids of New Caledonia: A case for reactivated subduction and slab break-off. Island Arc, v. 14, no. 3, p. 254-271.

Cluzel, D., P. Maurizot, J. Collot, and B. Sevin (2012), An outline of the geology of New Caledonia; from Permian-Mesozoic South-Gondwana active margin to Tertiary obduction and supergene evolution, Episodes, 35(1), p. 72-86.

Cluzel, D., Picard, C., Aitchison, J. C., Laporte, C., Meffre, S., and Parat, F., (1997), La nappe de Poya (ex-Formation des Basaltes) de Nouvelle-Calédonie (Pacifique sud-ouest): un plateau océanique campanien-paléocène supérieur obducté à l'Eocène supérieur, Comptes Rendus de l'Académie des Sciences - Series IIA - Earth and Planetary Science, v. 324, p. 443-451.

Collot, J., Geli, L., Lafoy, Y., Vially, R., Cluzel, D., Klingelhoefer, F., and Nouzé, H., (2008), Tectonic history of northern New Caledonia Basin from deep offshore seismic reflection: Relation to late Eocene obduction in New Caledonia, southwest Pacific. Tectonics, v. 27, no. 6., 20 p.

Collot, J., Patriat, M., Etienne, S., Rouillard, P., Soetaert, F., Juan, C., Marcaillou, B., Palazzin, G., Clerc, C., Maurizot, P., Pattier, F., Tournadour, E., Sevin, B., and Privat, A., (2017). Deepwater Fold-and-Thrust Belt Along New Caledonia's Western Margin: Relation to Postobduction Vertical Motions. Tectonics, v. 36, no. 10, p. 2108-2122.

Coudray, J., (1975), Recherches sur le Néogène et le Quaternaire marin de la NouvelleCalédonie. Contribution de l'étude sédimentologique à la connaissance de l'histoire géologique post-éocène, Thèse de Doctorat, Université des Sciences et Techniques du Languedoc, 446 p.

Dalrymple, R. W., Zaitlin, B. A., and Boyd, R., (1992). Estuarine facies models; conceptual basis and stratigraphic implications. Journal of Sedimentary Research, v. 62, no. 6, p. 1130-1146.

De Boer, W.F., (2007). Seagrass-sediment interactions, positive feedbacks and critical thresholds for occurrence: a review. Hydrobiologia, v. 591, p. 5-24.

Dubois, J., Launay, J., and Recy, J., (1974). Uplift movements in New Caledonia-Loyalty Islands area and their plate tectonics interpretation. Tectonophysics, v. 24, no. 1, p. 133-150.

Eva, A.N., (1980). Pre-Miocene seagrass communities in the Caribbean. Palaeontology, v. 23, 231-236.

Fabricius, K.E., (2005). Effects of terrestrial runoff on the ecology of corals and coral reefs: review and synthesis. Marine Pollution Bulletin, v. 50, p. 125-146.

Fournier, F., Montaggioni, L., and Borgomano, J., (2004). Paleoenvironments and highfrequency cyclicity from Cenozoic South-East Asian shallow-water carbonates: a case study from the Oligo-Miocene buildups of Malampaya (Offshore Palawan, Philippines), Marine and Petroleum Geology, v. 21, no. 1, p. 1-21.

Fujita, K; Hallock, P (1999). A comparison of phytal substrate preferences of Archaias angulatus and Sorites orbiculus in mixed macroalgal-seagrass beds in Florida Bay. Journal of Foraminiferal Research, v. 29, no. 2, p. 143-151 
899

900

901

902

903

904

905

906

907

908

909

910

911

912

913

914

915

916

917

918

919

920

921

922

923

924

925

926

927

928

929

930

931

932

933

934

935

936

937

938

939

940

941

942

943

944

945

946

947

948

949

950

Fujita, K., Asami, R., Takayanagi, H., and Iryu, Y. (2015) Carbonate sedimentation in seagrass beds on Ishigaki-jima, Ryukyu Islands, southwestern Japan. Island Arc, 24, p. 263-279

Gaina, C., Müller, D. R., Royer, J. Y., Stock, J., Hardebeck, J., and Symonds, P., (1998). The tectonic history of the Tasman Sea: a puzzle with 13 pieces. Journal of Geophysical Research: Solid Earth (1978-2012), v. 103, no. B6, p. 12413-12433.

Galloni F., Cornee J.J., Rebelle M. \& Ferrandini M. (2001) Sedimentary anatomies of early Miocene coral reefs in South Corsica (France) and South Sardinia. Géologie Mediterranéenne, v. 28, 73-77.

Garcin, M., Baills, A., Le Cozannet, G., Thomas, T., Auboin, A. L., and Sauter, J., (2013). Pluridecadal impact of mining activities on coastline mobility of estuaries of New Caledonia (South Pacific), Journal of Coastal Research, v. 65, p. 494-499.

Gubler, Y., and Pomeyrol, R., (1948), Existence de Néogène marin en Nouvelle-Calédonie. Comptes Rendus de l'Académie des Sciences, v. 226, p. 1292-1293.

Haig, D.W., Smith, M.G., Riera, R., Parker, J.H., (2020). Widespread seagrass meadows during the Early Miocene (Burdigalian) in southwestern Australia paralleled modern seagrass distributions. Palaeogeography, Palaeoclimatology, Palaeoecology, v. 555, 109846.

Hallock, P., and Glenn, E. C., (1986). Larger Foraminifera: A Tool for Paleoenvironmental Analysis of Cenozoic Carbonate Depositional Facies. Palaios, v. 1, no. 1, p. 55-64.

Hallock, P., Sheps, K., Chapronière, G., Howell, M., (2006). Larger benthic foraminifers of the Marion Plateau, northeastern Australia (ODP Leg 194): comparison of faunas from bryozoan (Sites 1193 and 1194) and red algal (Sites 1196-1198) dominated carbonate platforms. In: Anselmetti, F.S., Isern, A.R., Blum, P., Betzler, C. (Eds.), Proceedings ODP, Scientific Results, pp. 131.

Haq, B. U., Hardenbol, J., and Vail, P. R., (1987). Chronology of Fluctuating Sea Levels Since the Triassic. Science, v. 235, no. 4793, p. 1156-1167.

Harper, B., Puga-Bernabéu, A., Droxler, A. W., Webster, J. M., Gischler, E., Tiwari, M., LadoInsua, T., Thomas, A., L., Morgan, S., Luigi, J., and Rohl, U., (2015). Mixed carbonatesiliciclastic sedimentation along the Great Barrier Reef upper slope: A challenge to the reciprocal sedimentation model. Journal of Sedimentary Research, v. 85, no. 9, p. 1019-1036.

Hernández-Arana, H., Vega-Zepeda, A.A., Ruíz-Zárate, M.A., Falcón-Álvarez, L.I., LópezAdame, H., Herrera-Silveira, J., Kaster, J., (2015) Transverse coastal corridor: from freshwater lakes to coral reefs ecosystems . In: Islebe, G.A., Calmé, S., León-Cortés J.L., et Schmook, B., (Eds.), Biodiversity and Conservation of the Yucatán Peninsula, Cham: Springer International Publishing, pp. 355-376.

Holmes, A., (1965). Principles of physical geology, 2nd ed, Thomas Nelson, London, 730 pp.

Iseppi, M., Sevin, B., Cluzel, D., Maurizot, P., and Le Bayon, B., (2018). Supergene Nickel ore deposits controlled by gravity-driven faulting and slope failure, peridotite nappe, New Caledonia, Economic Geology, v. 113, no. 2, p. 531-544. 
951

952

953

954

955

956

957

958

959

960

961

962

963

964

965

966

967

968

969

970

971

972

973

974

975

976

977

978

979

980

981

982

983

984

985

986

987

988

989

990

991

992

993

994

995

996

997

998

999

1000

1001

1002

James, N.P., and Bone, Y. (2007). A Late Pliocene-Early Pleistocene, inner-shelf, subtropical, seagrass-dominated carbonate: Roe Calcarenite, Great Australian Bight, Western Australia. Palaios, v. 22, p. 343-359.

van Katwijk, M.M., Meier, N., van Loon, R., van Hove, E., Giesen, W., van der Velde, G., den Hartog, C., (1993). Sabaki River sediment load and coral stress: correlation between sediments and condition of the Malindi-Watamu reefs in Kenya (Indian Ocean): Marine Biology, v. 117, p. 675-683.

Kerans, C., and Tinker, S. W. (1999). Extrinsic stratigraphic controls on development of the Capitan reef complex. SEPM special publication, no. 65, p. 15-36

Lafoy, Y., Dupont, J., Missegue, F., Le Suave, R., and Pautot, G., (1995), Effets de la collision «ride des Loyauté-arc des Nouvelles-Hébrides» sur la terminaison sud de l'ensemble "Nouvelle-Calédonie-Loyauté ». Comptes Rendus de l'Académie des Sciences - Series IIA - Earth and Planetary Science, 320, p. 1101-1108.

Lagabrielle, Y., and Chauvet, A., (2008). The role of extensional tectonics in shaping Cenozoic New-Caledonia, Bulletin de la Société Géologique de France, v. 179, no. 3, p. 315-329.

Langer, M. R., (1993), Epiphytic foraminifera, Marine Micropaleontology, v. 20, p. 235-265.

Le Roy, P., Jorry, S., Jouet, G., Ehrhold, A., Michel, G., Gautier, V. and Guérin, C. (2019). Late Pleistocene evolution of the mixed siliciclastic and carbonate southwestern New Caledonia continental shelf/lagoon. Palaeogeography, Palaeoclimatology, Palaeoecology, v. 514, p. 502521.

Lukasik, J.J., James, N.P., McGowran, B., and Bone, Y. (2000): An epeiric ramp: low-energy, cool-water carbonate facies in a Tertiary inland sea, Murray Basin, South Australia. Sedimentology, v. 47, p. 851-881.

Madsen, J. D., P. A. Chambers, W. F. James, E. W. Koch, and D. F. Westlake, (2001). The interaction between water movement, sediment dynamics and submersed macrophytes. Hydrobiologia, v. 444, p. 71-84.

Mateu-Vicens, G., Hallock, P., Brandano, M., (2008). A depositional model and paleoecological reconstruction of the Lower Tortonian distally steepened ramp of Menorca (Balearic Islands, Spain). Palaios, v. 23, 465-481.

Mateu-Vicens, G., Hallock, P., Brandano, M. (2009). Test shape variability of Amphistegina D'Orbigny 1826 as a paleobathymetric proxy: application to two Miocene examples. In: Demchuk, T., Gary, A. (Eds.), Geologic Problems Solving with Microfossils. SEPM Spec. Publ., pp. $67-82$

Mateu-Vicens, G., Box, A., Deudero, S., and Rodriguez, B., (2010). Comparative analysis of epiphytic foraminifera in sediments colonized by seagrass Posidonia oceanica and invasive macroalgae Caulerpa spp. Journal of Foraminiferal Research, v. 40, p. 134-147.

Mateu-Vicens, G., Brandano, M., Gaglianone, G., Baldassarre, A., (2012). Seagrass-meadow sedimentary facies in a mixed siliciclastic-carbonate temperate system in the Tyrrhenian Sea (Pontinian Islands, Western Mediterranean). Journal of Sedimentary Research, v. 82, p. 451-463. 
1003

1004

1005

1006

1007

1008

1009

1010

1011

1012

1013

1014

1015

1016

1017

1018

1019

1020

1021

1022

1023

1024

1025

1026

1027

1028

1029

1030

1031

1032

1033

1034

1035

1036

1037

1038

1039

1040

1041

1042

1043

1044

1045

1046

1047

1048

1049

1050

1051

1052

1053

1054

1055

Mateu-Vicens, G., Khokhlova, A., and Sebastián-Pastor, T., (2014). Epiphytic foraminiferal indices as bioindicators in Mediterranean seagrass meadows, Journal of Foraminiferal Research, v. 44, p. 325-339.

Maurizot, P., Cabioch, G., Fournier, F., Leonide, P., Sebih, S., Rouillard, P., Montaggioni, L., Collot, J., Martin-Garin, B., Chaproniere, G., Braga, J. C., and Sevin, B., (2016). Post-obduction carbonate system development in New Caledonia (Népoui, Lower Miocene). Sedimentary Geology, v. 331, p. 42-62.

Maurizot, P., \& Vendé-Leclerc, M. (2009). New Caledonia geological map, scale 1/500000. Direction de l'industrie, des mines et de l'énergie-Service de la géologie de Nouvelle-Calédonie, Bureau de recherches géologiques et minières.

Mazzucchi, A., Tomassetti, L. (2011), Coral bioconstruction in a Burdiagalian mixzs siliciclastic-carbonate coastal system (Cala, Paraguano, Corsica), Journal of Mediterranean Earth Sciences, v. 3, p.15-23.

McNeill D.F., Cunningham K.J., Guertin L.A., and Anselmetti F.S., (2004). Depositional themes of mixed carbonate-siliciclastics in the South Florida Neogene: application to ancient deposits. In: Integration of outcrop and modern analogs in reservoir modeling. Am. Ass. Pet. Geol. Mem., v. 80, p. 23-43.

McNeill, D.F., Janson, X., Bergman, K.L., and Eberli, G.P., (2010). Belize: A Modern Example of a Mixed Carbonate-Siliciclastic Shelf. In: Westphal, H., Riegl, B., and Eberli, G.P., (Eds.) Carbonate depositional systems: assessing dimensions and controlling parameters: the Bahamas, Belize and the Persian/Arabian Gulf, Dordrecht: Springer Netherlands, pp. 81-143.

Miall, A. D., (1977). A review of the braided-river depositional environment. Earth-Science Reviews, v. 13, no. 1, p. 1-62.

Miall, A. D., (1985). Architectural-element analysis: A new method of facies analysis applied to fluvial deposits, Earth-Science Reviews, v. 22, no. 4, p. 261-308.

Miller, K. G., Kominz, M. A., Browning, J. V., Wright, J. D., Mountain, G. S., Katz, M. E., Sugarman, P. J., Cramer, B. S., Christie-Blick, N., and Pekar, S. F., (2005). The Phanerozoic Record of Global Sea-Level Change. Science, v. 310, no. 5752, p. 1293-1298.

Montaggioni, L. F., Cabioch, G., Thouveny, N., Frank, N., Sato, T., and Sémah, A.-M., (2011). Revisiting the Quaternary development history of the western New Caledonian shelf system: From ramp to barrier reef. Marine Geology, v. 280, no. 1, p. 57-75.

Moretti, I., and Turcotte, D., (1985). A model for erosion, sedimentation, and flexure with application to New Caledonia, Journal of geodynamics, v. 3, no. 1, p. 155-168.

Mortimer, N., Campbell, H. J., Tulloch, A. J., King, P. R., Stagpoole, V. M., Wood, R. A., Rattenbury, M. S., Sutherland, R., Adams, C. J., Collot, J., and Seton, M., (2017), Zealandia: Earth's Hidden Continent. The Geological Society of America, v. 27, p. 27-35.

Nemec, W., Steel, R.J., (1984), Alluvial and coastal conglomerates: Their significant features and some comments on gravelly mass flow deposits. In: Koster, E. H., and Steel, R. J. (Eds.), Sedimentology of Gravels and Conglomerates. Canadian Society of Petroleum Geologists Memoir, v. 10, pp. 1-31. 
1056

1057

1058

1059

1060

1061

1062

1063

1064

1065

1066

1067

1068

1069

1070

1071

1072

1073

1074

1075

1076

1077

1078

1079

1080

1081

1082

1083

1084

1085

1086

1087

1088

1089

1090

1091

1092

1093

1094

1095

1096

1097

1098

1099

1100

1101

1102

1103

1104

1105

1106

1107
Novak, V., Santodomingo, N., Rösler, A., Di Martino, E., Braga, J.C., Taylor, P.D., Johnson, K.G. and Renema, W. (2013) Environmental reconstruction of a late Burdigalian (Miocene) patch reef in deltaic deposits (East Kalimantan, Indonesia). Palaeogeography, Palaeoclimatology, Palaeoecology, v. 374, p. 110-122.

Novak, V., and Renema, W., (2015). Larger foraminifera as environmental discriminators in Miocene mixed carbonate-siliciclastic systems. Palaios, v. 30, p. 40-52.

Olivier, N., Carpentier, C., Martin-Garin, B., Lathuilière, B., Gaillard, C., Ferry, S., Hantzpergue, P., and Geister, J. (2004). Coral-microbialite reefs in pure carbonate versus mixed carbonate-siliciclastic depositional environments: the example of the Pagny-sur-Meuse section (Upper Jurassic, northeastern France). Facies, v. 50, p. 229-255.

Orpin, A. R., Brunskill, G.J., Zagorskis, I., and Woolfe, K. J., (2004). Patterns of mixed siliciclastic-carbonate sedimentation adjacent to a large dry-tropics river on the central Great Barrier Reef shelf, Australia. Australian Journal of Earth Sciences, v. 51, no. 5, pp. 665-683.

Page, M.C., Dickens, G.R., and Dunbar, G.B., (2003). Tropical view of Quaternary sequence stratigraphy: Siliciclastic accumulation on slopes east of the Great Barrier Reef since the Last Glacial Maximum. Geology, v. 31, no 11, p. 1013-1016.

Paquette, J.-L., and Cluzel, D., (2006). U-Pb zircon dating of post-obduction volcanic-arc granitoids and a granulite-facies xenolith from New Caledonia. Inference on Southwest Pacific geodynamic models. International Journal of Earth Sciences, v. 96, no. 4, p. 613-622.

Paris, J. P., (1981). Géologie de la Nouvelle-Calédonie, Un essai de synthèse, Mémoire du BRGM, v. 113, Orléans, France.

Pérès, J.M. and Picard, J. (1964) Nouveau Manuel de Bionomie benthique de la mer Méditerranée. Rec. Trav. Stat. Mar. Endoume, 3, p. 1-137.

Perry, C.T., Smithers, S.G., Gulliver, P., and Browne, N.K., (2012). Evidence of very rapid reef accretion and reef growth under high turbidity and terrigenous sedimentation. Geology, v. 40, p. 719-722.

Pomar, L., Mateu-Vicens, G., Morsilli, M., and Brandano, M., (2014), Carbonate ramp evolution during the Late Oligocene (Chattian), Salento Peninsula, southern Italy: Palaeogeography, Palaeoclimatology, Palaeoecology, v. 404, p. 109-132.

Posamentier, H. W., and Walker, R. G., (2006). Facies Models Revisited. SEPM Society for Sedimentary Geology, Special publication, v. 84.

Reich, S., Wesselingh, F.P., and Renema, W., (2014). A highly diverse molluscan seagrass fauna from the early Burdigalian (early Miocene) of Banyunganti (south-central Java, Indonesia). Ann. Nat. Hist. Mus. Wien. Ser. A, v. 116, p. 5-129.

Reich, S., Di Martino, E., Todd, J.A., Wesselingh F.P and Renema, W. (2015) Indirect paleoseagrass indicators (IPSIs): A review. Earth-Sci. Rev., 143, p. 161-186.

Renema, W. (2003) Larger foraminifera on reefs around Bali (Indonesia). Zoologische Verhandelingen Leiden, 345, p. 337-366. 
Renema, W. (2005) Depth estimation using diameter-thickness ratio in larger benthic foraminifera, Lethaia, v. 38, p. 137-141.

Renema, W. (2010) Is increased calcarinid (foraminifera) abundance indicating a larger role for macro-algae in Indonesian Plio-Pleistocene coral reefs? Coral Reefs, 29, p. 165-173.

Reuter, M., Piller, W.E., Harzhauser, M., Kroh, A., Rögl, F., Coric, S., (2011). The Quilon Limestone, Kerala Basin, India: an archive for Miocene Indo-Pacific seagrass beds. Lethaia, v. 44, 76-86.

Reuter, M., Piller, W.E., and Ehrart, C. (2012). A Middle Miocene carbonate platform under silici-volcaniclastic sedimentation stress (Leitha Limestone, Styrian Basin, Austria) Depositional environments, sedimentary evolution and palaeoecology. Palaeogeography, Palaeoclimatology, Palaeoecology, v. 350-352, p. 198-211.

Reynaud, J.-Y., and Dalrymple, R. W., (2012). Shallow-Marine Tidal Deposits, in: Davis R. A., and Dalrymple, R. W., eds., Principles of Tidal Sedimentology, Dordrecht, Springer Netherlands, p. 335-369.

Rigolot, P., and Pelletier, B., (1988). Tectonique compressive récente le long de la marge ouest de la Nouvelle-Calédonie: résultats de la campagne ZOE 400 du N/O Vauban (mars 1987): Comptes rendus de l'Académie des sciences. Série 2, Mécanique, Physique, Chimie, Sciences de l'univers, Sciences de la Terre, v. 307, no. 2, p. 179-184.

Rogers, C.S., (1990), Responses of coral reefs and reef organisms to sedimentation. Marine Ecology Progress Series, v. 62, p. 185-202.

Ryan-Mishkin, K, Walsh, J. P., Corbett, D. R. , Dail, M. B., and Nittrouer, J. A., (2009). Modern Sedimentation in a Mixed Siliciclastic-Carbonate Coral Reel Environment, La Parguera, Puerto Rico. Caribbean Journal of Science, v. 45, no.2-3, p. 151-167.

Sanders, D., and Baron-Szabo, R. C., (2005). Scleractinian assemblages under sediment input: their characteristics and relation to the nutrient input concept. Palaeogeography, Palaeoclimatology, Palaeoecology, v. 216, no.1, p. 139-181.

Santodomingo, N., Novak, V., Pretkovic, V., Marshall, N., Di Martino, E., Giudice Capelli, E., Rosler, A., Reich, S., Braga, J.C., Renema, W. and Johnson, K.G. (2015) A diverse patch reef from turbid habitats in the middle miocene (East Kalimantan, Indonesia). Palaios, v. 30, p. 128149.

Sevin, B., Cluzel, D., Maurizot, P., Ricordel - Prognon, C., Chaproniere, G., Folcher, N., and Quesnel, F., (2014). A drastic lower Miocene regolith evolution triggered by post obduction slab break-off and uplift in New Caledonia. Tectonics, v. 33, no. 9, p. 1787-1801.

Silver, B.A., and Robert G.T., (1968). Permian Cyclic Strata, Northern Midland and Delaware Basins, West Texas and Southeastern New Mexico1. AAPG Bulletin, v. 53, no. 11, p. 2223-2251.

Shinn, E. A., (1983). Tidal flat environment, Carbonate depositional environments. American Association of Petroleum Geologists, v. 33, p. 171-210.

Snedden, J. W., and Dalrymple, R. W., (1999), Modern shelf sand ridges: from historical perspective to a unified hydrodynamic and evolutionary model: SEPM Society for Sedimentary Geology, Special publication, v. 64, p. 13-28 
1162

1163

1164

1165

1166

1167

1168

1169

1170

1171

1172

1173

1174

1175

1176

1177

1178

1179

1180

1181

1182

1183

1184

1185

1186

1187

1188

1189

1190

1191

1192

1193

1194

1195

1196

1197

1198

1199

1200

1201

1202

1203

1204

1205

1206

1207

1208

1209

1210
Snedden, J. W., Kreisa, R. D., Tillman, R. W., Culver, S. J., and Schweller, W. J., (1999). An expanded model for modern shelf sand ridge genesis and evolution on the New Jersey Atlantic shelf. SEPM Society for Sedimentary Geology, Special publication, v. 64, p. 147-164.

Sola, F., Braga, J.C. and Aguirre, J. (2013) Hooked and tubular coralline algae indicate seagrass beds associated to Mediterranean Messinian reefs (Poniente Basin, Almería, SE Spain). Palaeogeogr. Palaeoclimatol. Palaeoecol., 374, p. 218-229.

Trescases, J. J., (1975). L'évolution géochimique supergène des roches ultrabasiques en zone tropicale : formation des gisements nickélifères de Nouvelle-Calédonie. Mémoires ORSTOM, v. 78, $280 \mathrm{p}$.

Tomás, S., Gianluca, F., Bömelburg, E., Zamagni, J., Perrin, C., Mutti M., (2016). Evidence for seagrass meadows and their response to paleoenvironmental changes in the early Eocene (Jafnayn Formation, Wadi Bani Khalid, N Oman). Sedimentary Geology, v. 341, pp. 189-202.

Tomassetti, L., Bosellini, F.R., Brandano, M., (2013). Growth and demise of a coral bioconstruction on a granite rocky substrate (Bonifacio basin, southeastern Corsica). Facies, v. 59, 703-716.

Tomassetti, L., Benedetti, A., Brandano, M., (2016). Middle Eocene seagrass facies fromApennine carbonate platforms (Italy). Sedimentary Geology, v. 335, 136-149.

Tucker, M.E. and Wright, V.P. (1990) Carbonate sedimentology. Blackwell scientific publications. Oxford, pp. 482.

Uchman, A. and Pervesler, P. (2007), Palaeobiological and palaeonvironmental significance of the Pliocene trace fossilDactyloidites peniculus. Acta Palaeontologica Polonica v. 52, no 4 p.799808.

Vigorito M., Murru M., Simone L .(2012). Carbonate production in rift basins: models for platform inception, growth and dismantling and for shelf to basin sediment transport, Miocene Sardinia Rift Basin, Italy. In: M. Mutti, W. Piller and C. Betzler (Eds.) Carbonate Systems during the Oligocene-Miocene Climatic Transition, IAS Special Publication, v. 42, 257-282.

Willis, B. J., Bhattacharya, J. P., Gabel, S. L., and White, C. D., (1999). Architecture of a tide influenced river delta in the Frontier Formation of central Wyoming, USA. Sedimentology, v. 46, no. 4, p. 667-688.

Wilson, J. L., (1967). Cyclic and Reciprocal Sedimentation in Virgilian Strata of Southern New Mexico. GSA Bulletin, v. 78, no. 7, p. 805-818.

Wilson, M.E.J. (2005). Development of equatorial delta-front patch reefs during the Neogene, Borneo. J. Sediment. Res., v. 75, p. 114-133.

Zeller, M., Verwer, K., Eberli, G. P., Massaferro, J. L., Schwarz, E., and Spalletti, L., (2015). Depositional controls on mixed carbonate-siliciclastic cycles and sequences on gently inclined shelf profiles. Sedimentology, v. 62, no. 7, p. 2009-2037. 
1212

1213

1214

1215

1216

1217

1218

1219

1220

1221

1222

1223

1224

1225

1226

1227

1228

1229

1230

1231

1232

1233

1234

1235

1236

1237

\section{FIGURE AND TABLE CAPTIONS}

Figure 1: Simplified geological map of New Caledonia (modified after Maurizot \& Vendé-Leclerc, 2009) with location of the study area, western limit of obducted peridotites, drilling sites on the quaternary barrier reefs (Coudray, 1975; Cabioch et al., 2008; Montagionni et al., 2011), together with map extent of the Deep-Water Fold and Thrust Belt of the western margin of New Caledonia (DWFTB, Collot et al., 2017). See text for details of these features.

Figure 2: (A) Geological map of the Népoui are modified from Maurizot \& Vendé-Leclerc (2009), (B) cross section through the Kopeto massif and the Népoui miocene outcrops. The Lower Miocene mixed carbonate-siliciclastic system overlies unconformably the Eocene Népoui Flysch and the Poya Terrane on the western Caledonian margin. The Peridotite Nappe structurally overlies the Poya Terrane and the Nepoui Flysch.

Figure 3: Synthetic sedimentary log combining observations from the S4 well and outcrop sections. The Lower Miocene mixed system is composed of the Lower Népoui Formation (Aquitanian) and the Upper Népoui Formation (Burdigalian) dated by biostratigraphic analysis and strontium isotope measurements (Maurizot et al., 2016). Both formations are divided into three members A1 to A3 and B1 to B3 characterizing respectively a carbonate ramp and a mixed inner ramp delta system.

Figure 4: Location map of dataset used in this study. See location on Fig 1 and 2.

Figure 5: Description, sedimentary processes and summary depositional environment interpretation of the different facies associations of the Upper Népoui Formation (Burdigalian).

Figure 6: Proximal alluvial fan (FA1) 
A. Massive, sandy matrix supported, poorly sorted conglomerate of the NE Pindaï

1239

1240

1241

1242

1243

1244

1245

1246

1247

1248

1249

1250

1251

1252

1253

1254

1255

1256

1257

1258

1259

1260

1261

1262

1263

1264 Peninsula.

B. Altered serpentinite pebbles with silicified cortex and greenish sands.

C. Large block of dolerite that reach a diameter of $1 \mathrm{~m}$.

D. Gravelly sandstones with faint trough cross-bedding highlighted by gravels and pebbles.

E. "Piste de roulage" outcrop (NW Muéo Peninsula) showing the unconformity between the Népoui Flysch (Priabonian) and the Upper Népoui Formation (Burdigalian) (see location on Fig.4).

F. Miocene conglomerates of the Upper Népoui Formation organized in two normally graded sequences as shown on the sedimentological section.

Figure 7: Distal alluvial fan (FA2)

A. Oblique bedded conglomerates that vertically evolve into trough cross-bedded sandstones capped by a planar abandonment surface.

B. Meter scale oblique bedsets showing an apparent progradation towards the SSW.

C. Red to greenish-red trough cross-bedded sandstones with root traces and iron oxide concretions

D. Silicified wood pieces.

Figure 8: Fluvial channel fills (FA3)

A. Interpretation of the depositional architecture of two erosional channels in the northern part of the Didot Islet (see location in Fig.4)

B. Conglomeratic channel fill

C. Conglomerates with large pebbles within a coarse to very coarse-grained sandy matrix organized in graded beds with erosional trough-shaped bases.

D. Large silicified wood trunk. 
Figure 9: Tidal sands (FA4)

A. Small sigmoidal dunes showing tidal bundling and small scale trough-cross ripples between lamina sets

B. Herring-bone cross-bedding

D. Greenish coarse to medium-grained cross-bedded sandstones.

E. Thin section from the S2 well cores (85.6 m depth) showing altered serpentinite grains with radial fibrous cement and drusy cement.

1274

1275

1276

Figure 10: Subtidal sands (FA5)

A. Fine-grained bioturbated sandstones with planar laminations and small-scale ripples

B. Isolated unidirectional ripples

C. Dactyloidites peniculus burrows in fine-grained sandstones

D. Fine-grained bioturbated and laminated sandstones.

Figure 11: Subtidal, seagrass related low-angle carbonate ramp (FA6)

A. Outcrop of the southern part of Grimault Islet (see location Fig. 4).

B. Focus on the southern part of Grimault Islet outcrop that shows foraminiferalcoralline algal packstone-grainstone facies.

C. Calcitic tubes are sparsely distributed over carbonate ramp deposits. They could be interpreted as tube worms.

D. Isolated corals and lags of ultramafic sub-angular pebbles and cobbles in a carbonate matrix.

E. Thin section from the S2 well core (41.25 m depth) showing two types of dolomite crystals: clear large rhomboidal crystals and small rhomboidal crystals with cloudy centers. 
F. Karstified and dolomitized facies of the Nepü Member from S2 well cores (see location on Fig.4). Karst features and fractures are filled by mustard yellow clay, carbonate fragments and impregnated red mud.

G. Small-sized in situ coral bioconstructions embedded within coral floatstones and foraminiferal-coraline algal packstones-grainstones.

Figure 12: Simplified logs of the nine shallower drilled boreholes of the Pindaï Peninsula and Grimault Islet (see location Fig.4). Stars represent the locations of the thin sections.

Figure 13: Seagrass-related carbonate microfacies from the Burdigalian of Népoui (FA6) (see location of thin sections on Figure 12):

A. Foraminiferal-coralline algal packstone with abundant disk-shaped soritids (Sor.) and miliolids including Austrotrillina (Austr.). Grimault Island, well GR07, depth: 11.10 m.

B. Foraminiferal-coralline algal packstone with disk-shaped soritids (Sor.), small rotalids (Rot.), Halimeda (Hal.), articulated coralline algae (ARA), Planorbulina (Plan.) and lithoclasts (Lith.). Pindaï Peninsula, well 99N014, depth: 27.80m;

C. Foraminiferal-coralline algal packstone with disk-shaped soritids (Sor.), Austrotrillina (Austr.), the alveolinid Flosculinella (Alv.), articulated coralline algae (ARA) and Small miliolids (Mil.) Pindaï Peninsula, well 96N004, depth: 1.50m;

D. Foraminiferal-coralline algal packstone with small rotalids (Neorotalia) (Rot.), articulated coralline algae (ARA) and lithoclasts (Lith.). Pindaï Peninsula, well 99N014, depth: 27.80m;

E. Foraminiferal-coralline algal packstone with encrusting formainifers Victoriellids (Vict.), Gypsina (Gyps.) and small rotalids (Rot.). Pindaï Peninsula, well 96N002, depth: $11.10 \mathrm{~m}$;

Figure 14: Skeletal composition of the sand-grained skeletal fraction of seagrass-related

F. Foraminiferal-coralline algal grainstone with disk-shaped soritids (Sor.), rotalids (Rot.), the alveolinid Flosculinella (Alv.) and articulated coralline algae (ARA). Grimault Island, well GR07.

\footnotetext{
carbonates (FA6) using point counting on thin-sections.
} 
1323

1324

1325

1326

1327

1328

1329

1330

1331

1332

1333

1334

1335

1336

1337

1338

1339

1340

1341

1342

1343

1344

1345

1346

1347

1348

Figure 15: Subaqueous distributary channel fills (FA7).

A. The Wharf outcrop (see location Fig.4) showing a channel complex incising inner carbonate ramp and tidal flat deposits.

B. Close-up on carbonate matrix-supported conglomerates that fill channels.

C. The Baie des Sapins outcrop (see location Fig. 4) displays meter-scale isolated channels incising into carbonate ramp deposits.

Figure 16: Carbonate-dominated tidal flat deposits (FA8)

A. Marls interbedded with very fine-grained sandstones with plant debris.

B. Oblique sets of very bioturbated gravelly sandstones with truncated topsets.

C. Marls interbedded with very fine-grained sandstones and lithoclastic limestones intersected by pneumatophores roots.

D. Lag of well-sorted ultramafic pebbles in a carbonate matrix.

Figure 17: (A) Synthetic sedimentary log of S2 well (scale 1/500) (see location Fig.4). (B). Top of Lower Népoui Formation (Aquitanian), between -104 and -98 m, characterized by scleratinian floastones with a foraminiferal-algal grainstone-packstone matrix containing miogypsinids (miog.) and articulated coralline algae (ARA) (C). The lower part of the Upper Nepoui Formation (Burdigalian), between -98 to $-83 \mathrm{~m}$, characterized by fine to coarse-grained sandstones coarsening upward (FA4-FA5) that contain weathered serpentinite grains (Litho.), ferricrete clasts and few benthic foraminifers (miog.: miogypsinids). D. Népü Limestone Member (B3), between -80 to $0 \mathrm{~m}$, showing pervasive karstification and laterite mud ( $\mathrm{Im}$ ) infills on cores. The thin section $(-103 \mathrm{~m})$ exhibit significant dolomitization features with few preserved bioclasts (RA: coralline algal fragments) 
1350

1351

1352

1353

1354

1355

1356

1357

1358

1359

1360

1361

1362

1363

1364

1365

1366

1367

1368

1369

1370

1371

1372

1373

Figure 18: Synthetic sedimentary sections (scale: 1/500) revealing the frontal and lateral facies variability of the Upper Népoui Formation (Burdigalian).

A. Longitudinal profile within the proximal-distal sections of Muéo Peninsula, PindaïWharf and Pindaï S2 core sections.

B. Lateral profile across the Burdigalian mixed system with the Pindaï- Wharf, Grimault, Didot, Longue and Beco sections.

Figure 19: Depositional models for the mixed carbonate-siliciclastic system of Népoui (Burdigalian). (A) The burdigalian mixed system is first dominated by short alluvial fan deposits that laterally evolve distally into tidally influenced nearshore sandstone deposits and towards shallow water carbonate dominated by seagrass-related biota and corals derived from smallsized bioconstructions, and (B) is then overlain by seagrass-related carbonate ramp cut by several small-scale conglomerate channels.

Table 1: Skeletal composition of the sand-sized fraction (in \%) of FA6 limestones (seagrassrelated facies association) from point counting on thin-sections. The location of wells and outcrop samples is reported on Figure 4. Texture code: P=Packstone; G=Grainstone; FP: floatstone with packstone matrix. Foraminiferal assemblage code: $\mathrm{p}=$ porcelaneous-dominated epiphytic assemblage (Austrotrillina+ soritids + peneroplids); $r$ = rotalid-dominated epiphytic foraminiferal assemblage; $v$ = victoriellid-dominated foraminiferal assemblage.

Table 2: Skeletal composition of the sand fraction within FA6 limestones as a function of depositional texture and foraminiferal assemblage. 
Skeletal composition (\%)

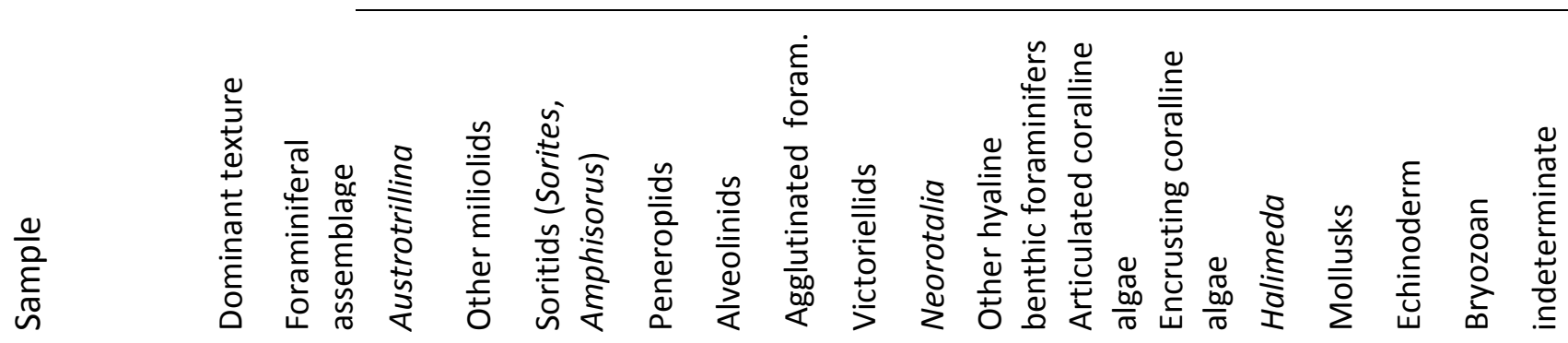

\begin{tabular}{|c|c|c|c|c|c|c|c|c|c|c|c|c|c|c|c|c|c|c|}
\hline Well 96N002 : $4.00 \mathrm{~m}$ & $\mathrm{P}$ & $p$ & 6 & 27 & & 8 & 1 & & 12 & & 4 & 7 & 19 & & 7 & 2 & & 7 \\
\hline Well 96N002 : $6.00 \mathrm{~m}$ & G & $p$ & 12 & 9 & 11 & & & 2 & & & 2 & 18 & 30 & & & 11 & 2 & 3 \\
\hline Well 96N002 : $8.10 \mathrm{~m}$ & G & $p$ & 4 & 17 & 21 & & & 7 & & 9 & 9 & 1 & 27 & & & 1 & & 4 \\
\hline Well 96N002: $11.10 \mathrm{~m}$ & $\mathrm{P}$ & $v$ & & & & & & & 47 & 16 & 11 & 2 & 12 & & 2 & 7 & & 3 \\
\hline Well 96N002: $19.80 \mathrm{~m}$ & $\mathrm{P}$ & $r$ & & 12 & 5 & & & & & 33 & 13 & 10 & 21 & & & & & 6 \\
\hline Well 96N004: $1.50 \mathrm{~m}$ & $\mathrm{P}$ & $p$ & 1 & 15 & 12 & 5 & 1 & 5 & & 8 & 2 & 28 & 14 & & 2 & 3 & & 4 \\
\hline Well 96N004 : $3.50 \mathrm{~m}$ & $\mathrm{P}$ & $r$ & & 3 & 10 & & & 3 & 3 & 17 & 1 & 37 & 14 & & 1 & 4 & & 7 \\
\hline Well 96N007: $21.50 \mathrm{~m}$ & $\mathrm{P}$ & $r$ & & 6 & & & & & 7 & 47 & 6 & 12 & 12 & & 3 & & & 7 \\
\hline Well 99N008: $24.70 \mathrm{~m}$ & $\mathrm{P}$ & $r$ & & 2 & 2 & 1 & & 4 & & 41 & 9 & 9 & 14 & & 5 & 6 & & 7 \\
\hline Well 99N008: $9.40 \mathrm{~m}$ & $\mathrm{P}$ & $p$ & 1 & 4 & 22 & & & 1 & 7 & 2 & 1 & 11 & 43 & & 2 & 3 & & 3 \\
\hline Well 99N008: $15.00 \mathrm{~m}$ & $\mathrm{P}$ & $p$ & & 3 & 13 & & & & & 10 & 3 & 4 & 14 & 14 & 9 & 26 & & 4 \\
\hline Well 99N012 : $8.80 \mathrm{~m}$ & $\mathrm{P}$ & $\mathrm{v}$ & & & & & & 1 & 39 & 39 & & 6 & 8 & & 1 & 3 & & 3 \\
\hline Well 99N014: $18.50 \mathrm{~m}$ & $\mathrm{P}$ & $r$ & & 12 & 8 & & & 5 & 1 & 21 & 4 & 14 & 17 & & 4 & 6 & & 8 \\
\hline Well 99N014: $27.80 \mathrm{~m}$ & $\mathrm{P}$ & $p$ & & 2 & 19 & & & 2 & & 15 & 6 & 15 & 13 & 8 & 2 & 7 & 2 & 9 \\
\hline Well 99N015: 16,25 m & FP & $r$ & & 5 & & & & 2 & 2 & 43 & 5 & 10 & 22 & & 2 & 2 & & 7 \\
\hline Well 99N017: $11.75 \mathrm{~m}$ & $\mathrm{P}$ & $p$ & 6 & 5 & 21 & & & 7 & 2 & & 6 & 21 & 15 & & 2 & 6 & & 9 \\
\hline Well 99N017: $22.00 \mathrm{~m}$ & $\mathrm{P}$ & $p$ & & 3 & 22 & & & 4 & 2 & 14 & 6 & 16 & 14 & & 5 & 7 & & 7 \\
\hline Well 99N017: $22.05 \mathrm{~m}$ & $\mathrm{P}$ & $p$ & 4 & 6 & 18 & & & 7 & 4 & 9 & 6 & 12 & 18 & & 2 & 6 & & 8 \\
\hline Well GR07 : $11.10 \mathrm{~m}$ & $\mathrm{G}$ & $\mathrm{p}$ & & & 25 & & & 2 & 4 & 3 & 1 & 29 & 25 & & 2 & 4 & & 5 \\
\hline CS26 (outcrop) & $\mathrm{G}$ & $r$ & 4 & 5 & 1 & & & 10 & 6 & 21 & 4 & 23 & 9 & & 0 & 9 & & 8 \\
\hline CS40 (outcrop) & FP & $\mathrm{v}$ & & 5 & 13 & & 2 & 4 & 20 & 8 & 4 & 14 & 16 & & 2 & 5 & & 7 \\
\hline 045_01 (outcrop) & G & $\mathrm{p}$ & & 9 & 22 & & & 2 & & 4 & 8 & 7 & 33 & & 2 & 6 & & 7 \\
\hline
\end{tabular}

Table 1: Skeletal composition of the sand-sized fraction (in \%) of FA6 limestones (seagrass-related facies association) from point counting on thin-sections. The location of wells and outcrop samples is reported on Figure

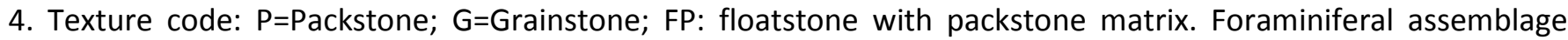
code: $p=$ porcelaneous-dominated epiphytic assemblage (Austrotrillina + soritids + peneroplids); $r=$ rotaliddominated epiphytic foraminiferal assemblage; $v$ = victoriellid-dominated foraminiferal assemblage. 
Skeletal composition (\%) of the sand-sized fraction

\begin{tabular}{|c|c|c|c|c|c|c|c|c|}
\hline 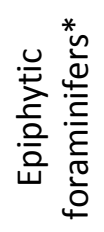 & 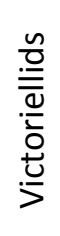 & 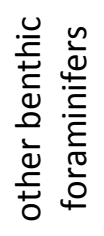 & 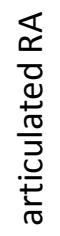 & 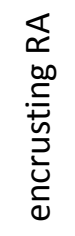 & $\begin{array}{l}\frac{\pi}{0} \\
\stackrel{d}{E} \\
\frac{.}{\bar{T}} \\
\frac{\pi}{I}\end{array}$ & $\begin{array}{l}\text { 흘 } \\
\text { 흘 }\end{array}$ & 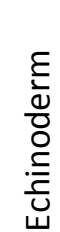 & $\begin{array}{l}5 \\
0 \\
0 \\
0 \\
0 \\
⿱ 乛 龰 \\
0\end{array}$ \\
\hline
\end{tabular}

\begin{tabular}{|c|c|c|c|c|c|c|c|c|c|c|c|}
\hline All samples & Average & 30 & 7 & 15 & 14 & 19 & 1 & 3 & 6 & 0 & 6 \\
\hline \multirow[t]{2}{*}{$\mathrm{N}=22$} & $\min$ & 14 & 0 & 1 & 1 & 9 & 0 & 0 & 0 & 0 & 3 \\
\hline & $\max$ & 47 & 47 & 33 & 37 & 43 & 14 & 9 & 26 & 2 & 9 \\
\hline \multirow{3}{*}{$\mathrm{N}=5$} & Average & 27 & 2 & 17 & 16 & 25 & 0 & 1 & 6 & 0 & 5 \\
\hline & $\min$ & 23 & 0 & 3 & 1 & 9 & 0 & 0 & 1 & 0 & 3 \\
\hline & $\max$ & 34 & 6 & 33 & 29 & 33 & 0 & 2 & 11 & 2 & 8 \\
\hline Packstones & Average & 30 & 8 & 14 & 13 & 17 & 1 & 3 & 5 & 0 & 6 \\
\hline \multirow[t]{2}{*}{$\mathrm{N}=17$} & $\min$ & 14 & 0 & 1 & 2 & 12 & 0 & 0 & 0 & 0 & 3 \\
\hline & $\max$ & 47 & 47 & 32 & 37 & 43 & 14 & 9 & 26 & 2 & 9 \\
\hline \multirow{3}{*}{$\begin{array}{l}\text { Samples with porcelaneous- } \\
\text { dominated epiphytic foraminiferal } \\
\text { assemblage }(N=12)\end{array}$} & Average & 27 & 3 & 16 & 14 & 22 & 2 & 3 & 7 & 0 & 6 \\
\hline & $\min$ & 14 & 0 & 3 & 1 & 13 & 0 & 0 & 1 & 0 & 3 \\
\hline & $\max$ & 36 & 12 & 33 & 29 & 43 & 14 & 9 & 26 & 2 & 9 \\
\hline \multirow{3}{*}{$\begin{array}{l}\text { Samples with calcarinid-dominated } \\
\text { epiphytic foraminiferal assemblage } \\
(\mathrm{N}=7)\end{array}$} & Average & 36 & 3 & 16 & 16 & 16 & 0 & 2 & 4 & 0 & 7 \\
\hline & $\min$ & 26 & 0 & 7 & 9 & 9 & 0 & 0 & 0 & 0 & 6 \\
\hline & $\max$ & 47 & 7 & 25 & 37 & 22 & 0 & 5 & 9 & 0 & 8 \\
\hline \multirow{3}{*}{$\begin{array}{l}\text { Samples with victoriellid-dominated } \\
\text { foraminiferal assemblage }(\mathrm{N}=3)\end{array}$} & Average & 24 & 34 & 9 & 7 & 14 & 0 & 2 & 5 & 0 & 4 \\
\hline & & 16 & 20 & 1 & 2 & 12 & 0 & 1 & 3 & 0 & 3 \\
\hline & $\max$ & 36 & 47 & 15 & 14 & 16 & 0 & 2 & 7 & 0 & 7 \\
\hline
\end{tabular}

Table 2: Skeletal composition of the sand fraction within FA6 limestones as a function of depositional texture and foraminiferal assemblage. 
Figure 1

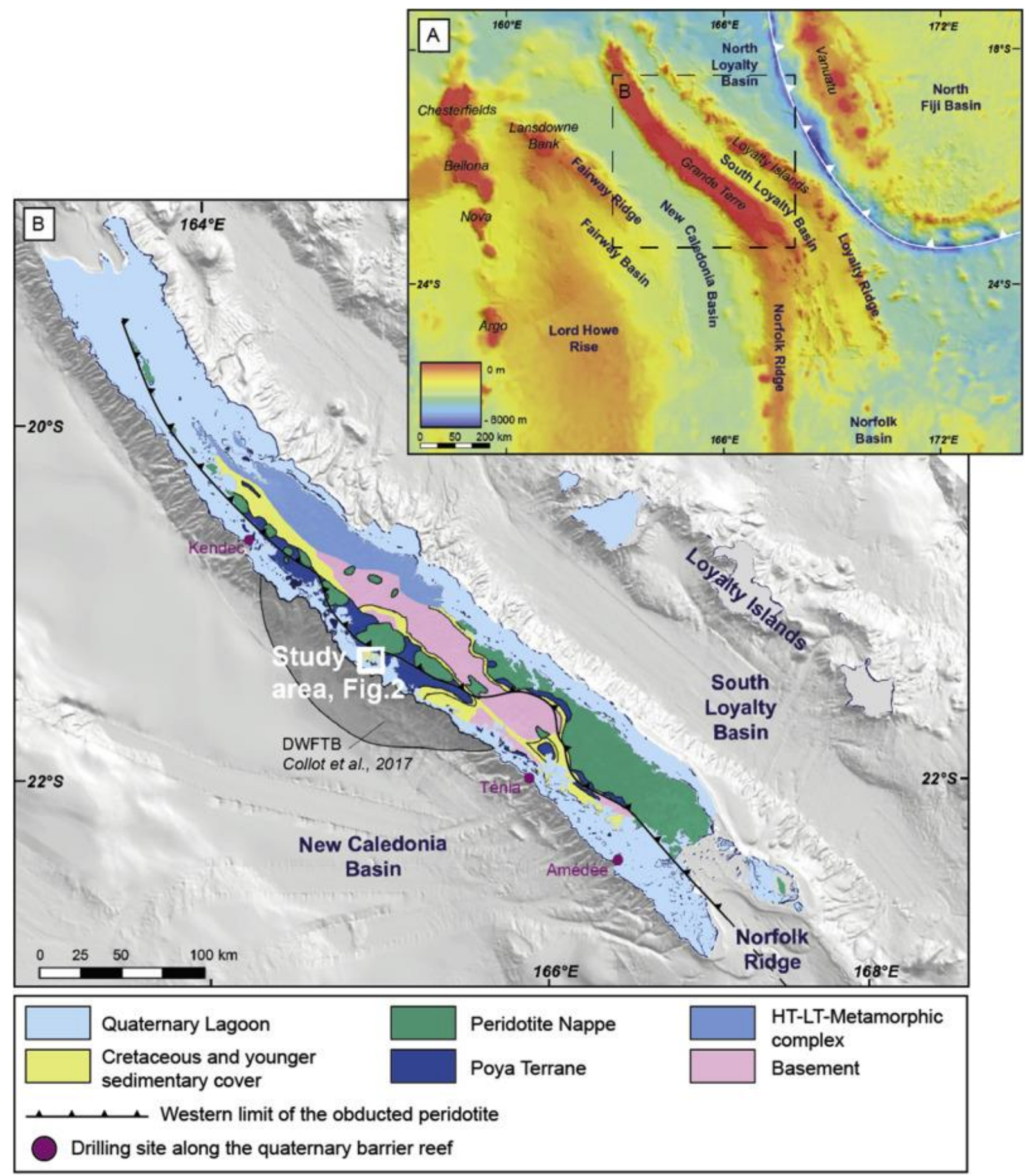


Figure 2
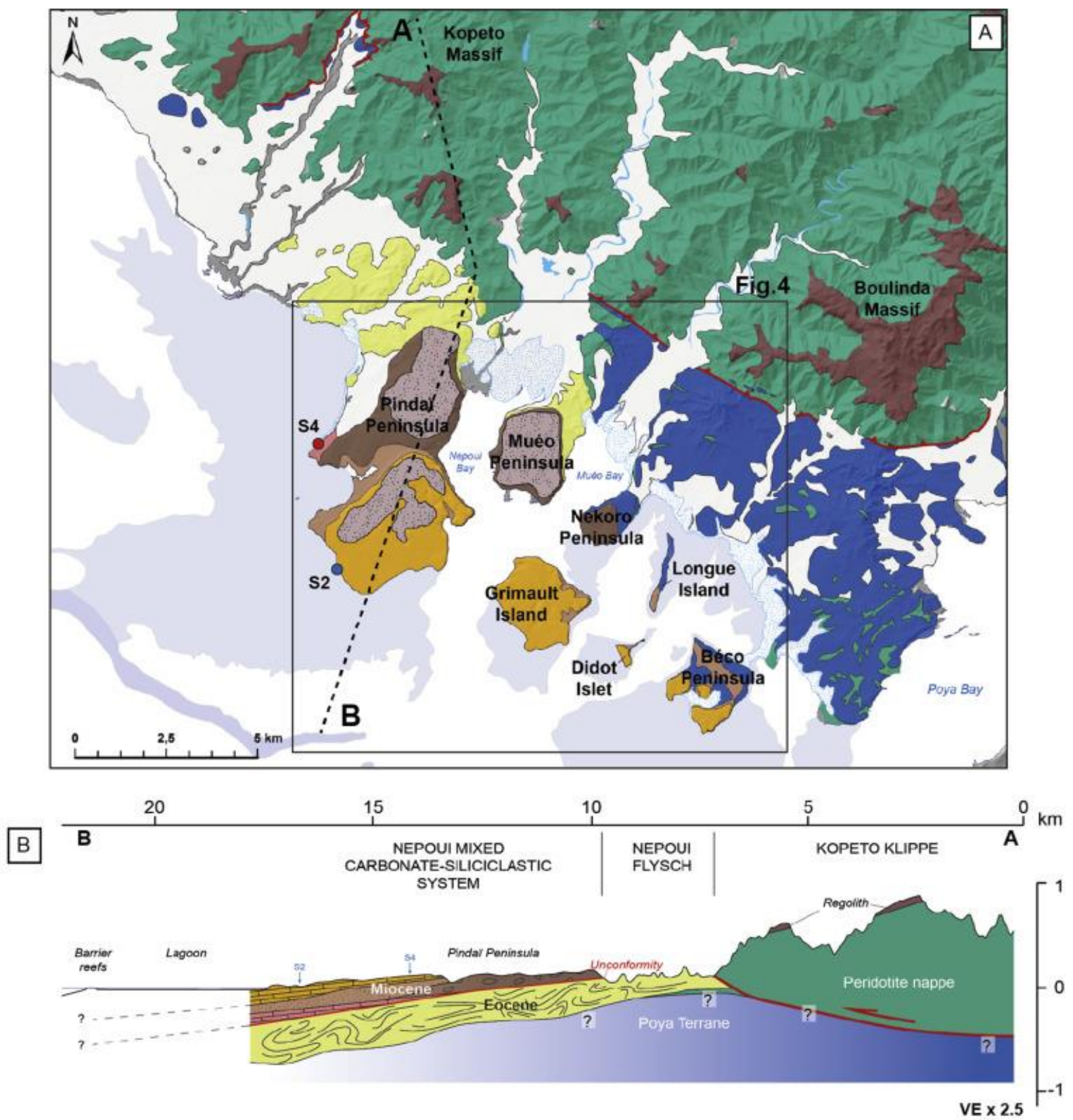

POST-OBDUCTION

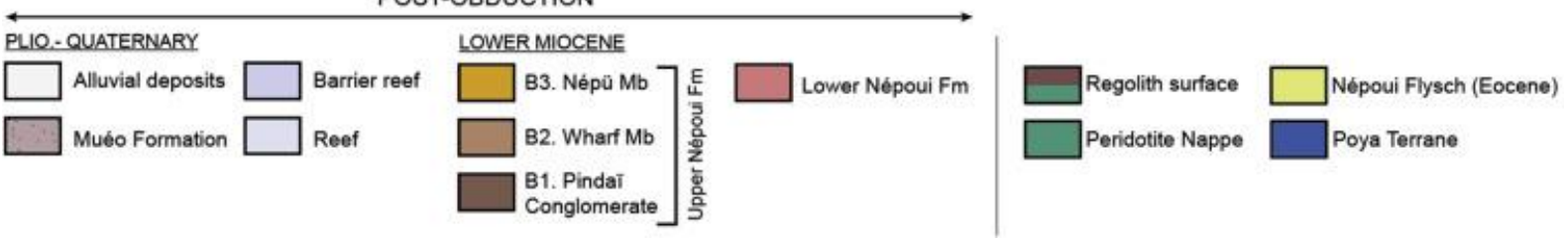


Figure 3

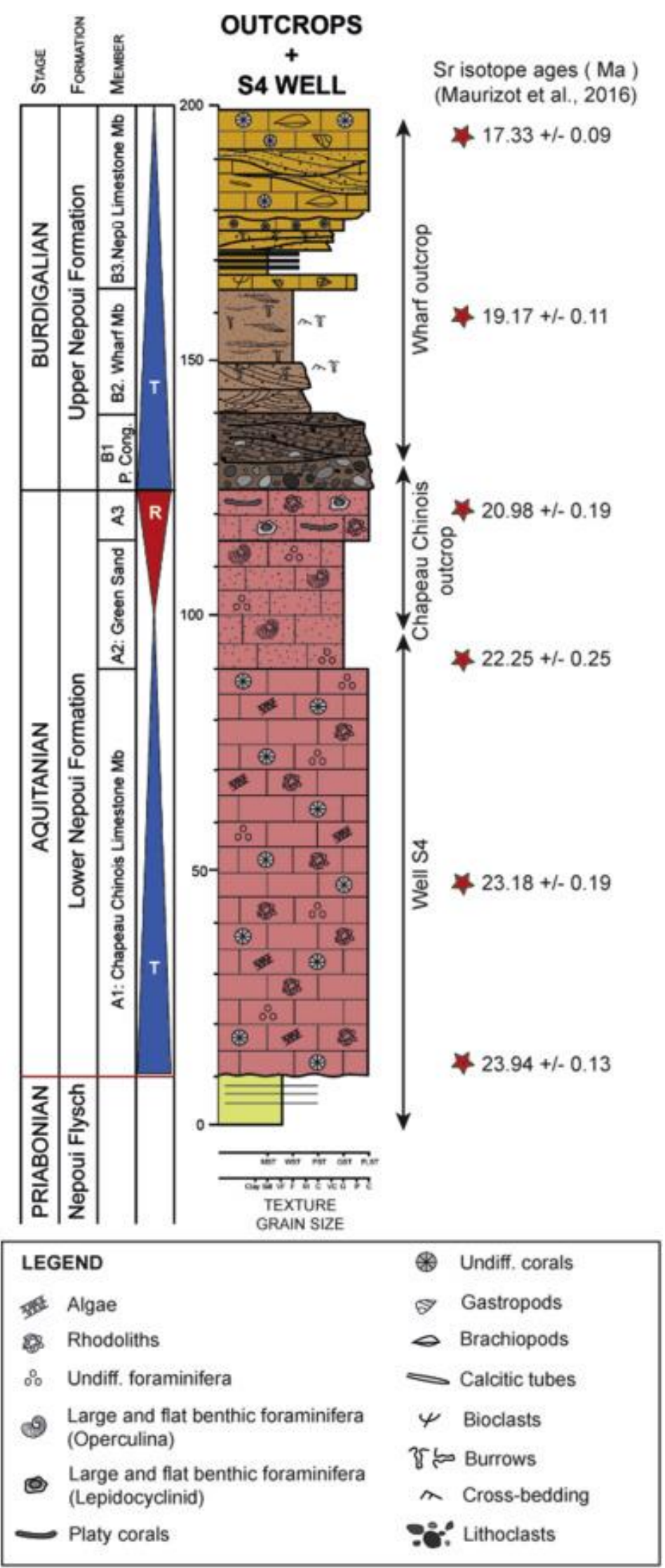


Figure 4
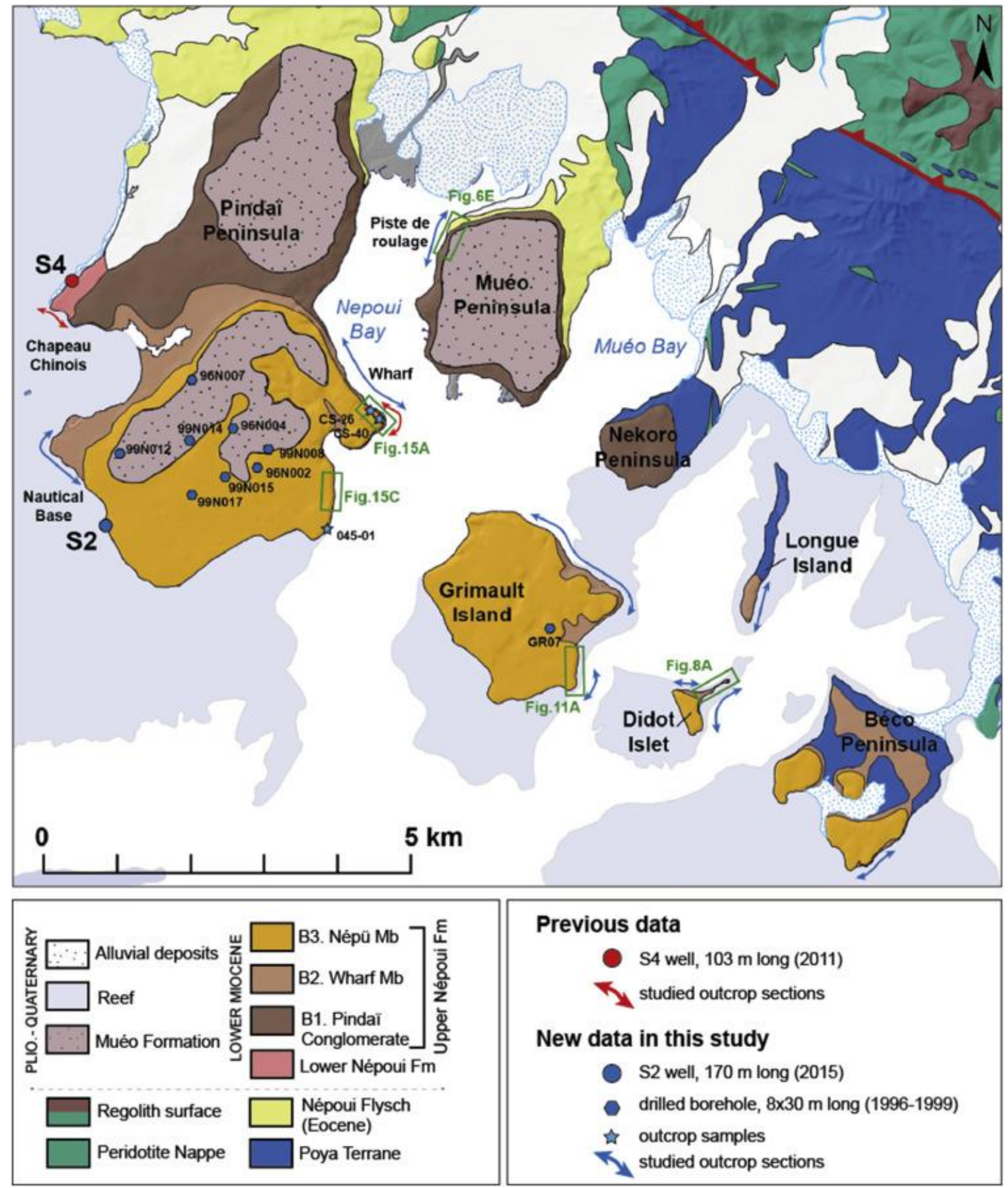

\section{Previous data}

S4 well, 103 m long (2011)

Th studied outcrop sections

\section{New data in this study}

S2 well, $170 \mathrm{~m}$ long (2015)

- drilled borehole, $8 \times 30 \mathrm{~m}$ long (1996-1999)

outcrop samples

studied outcrop sections 
Figure 5

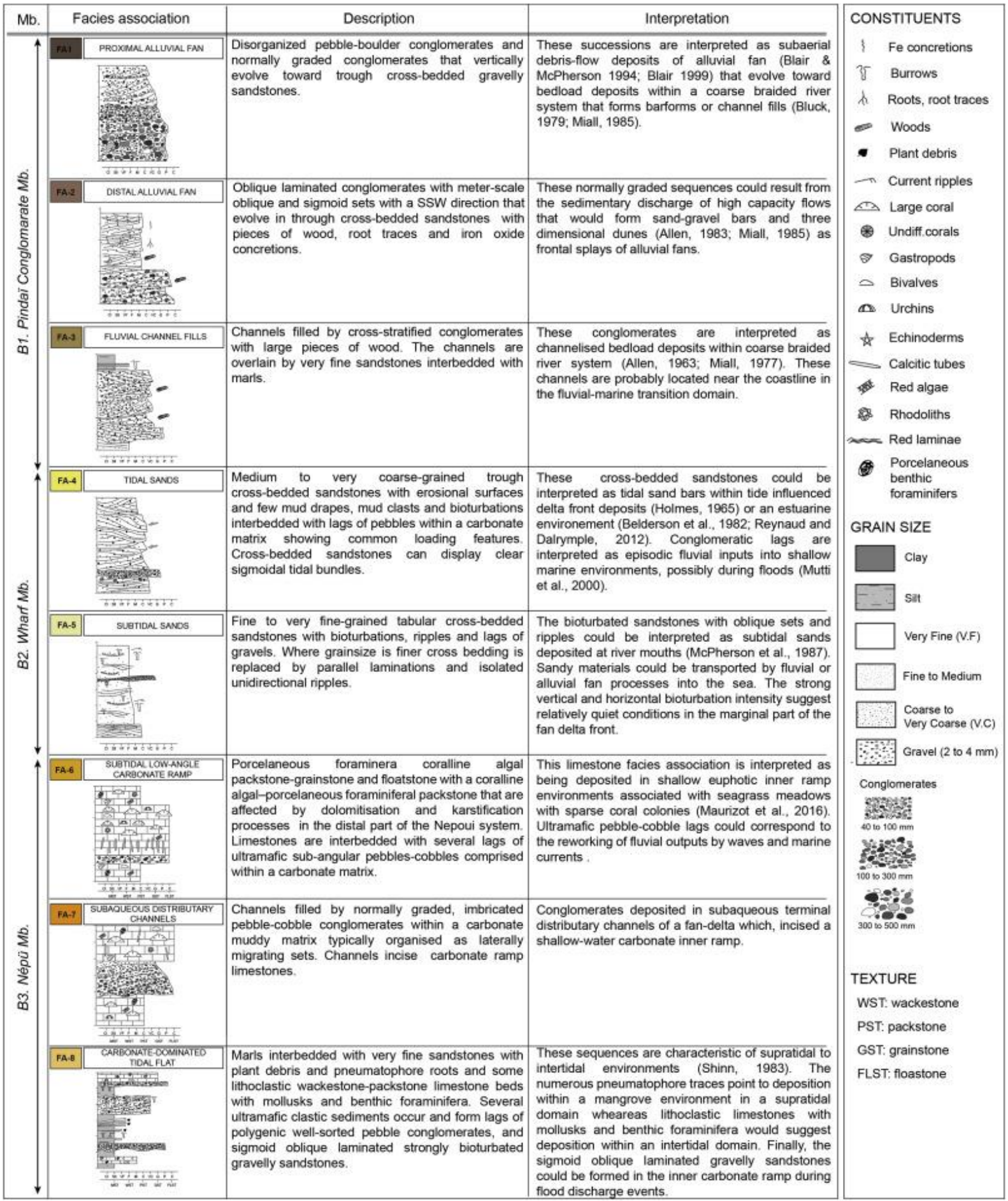


Figure 6
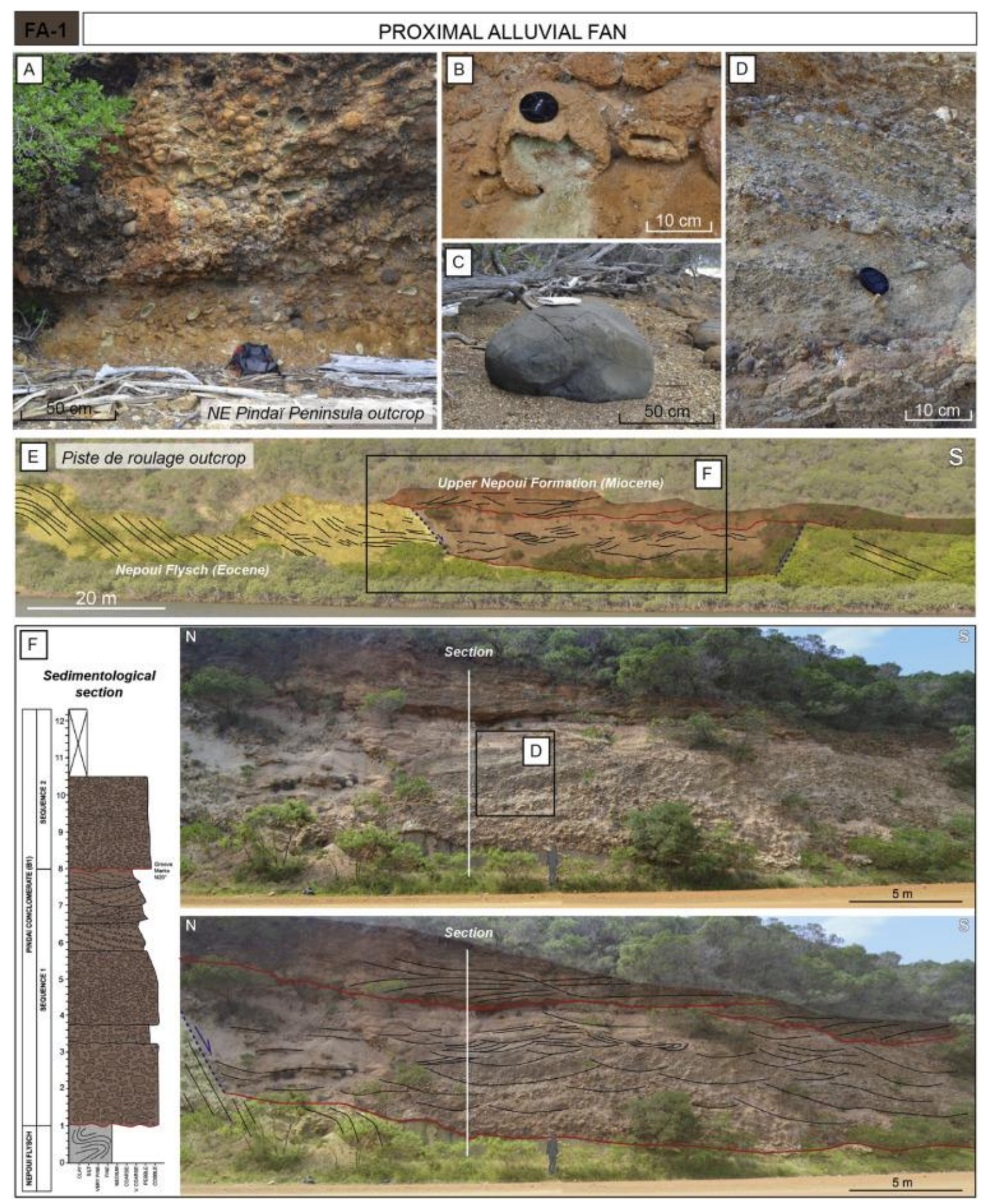
Figure 7
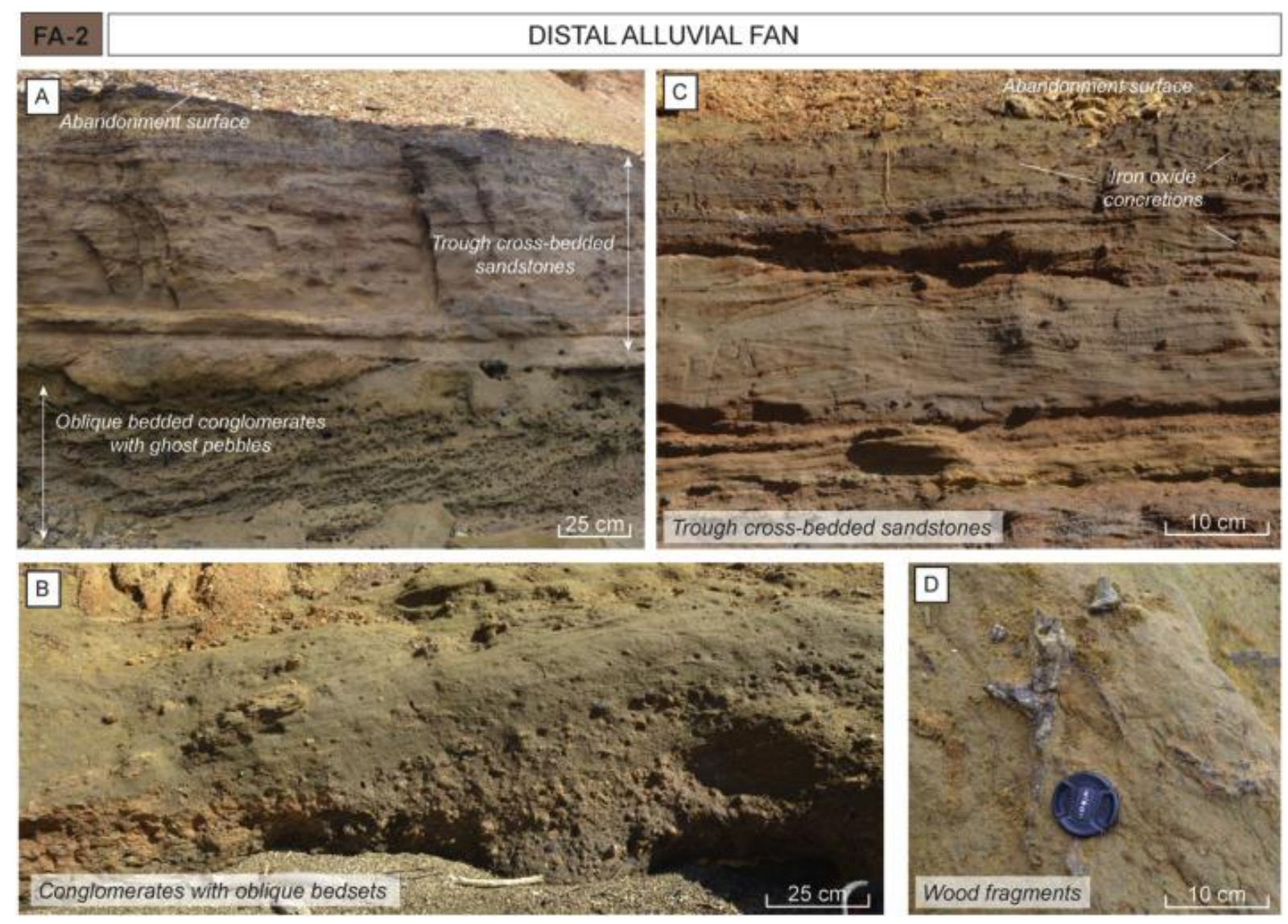
Figure 8
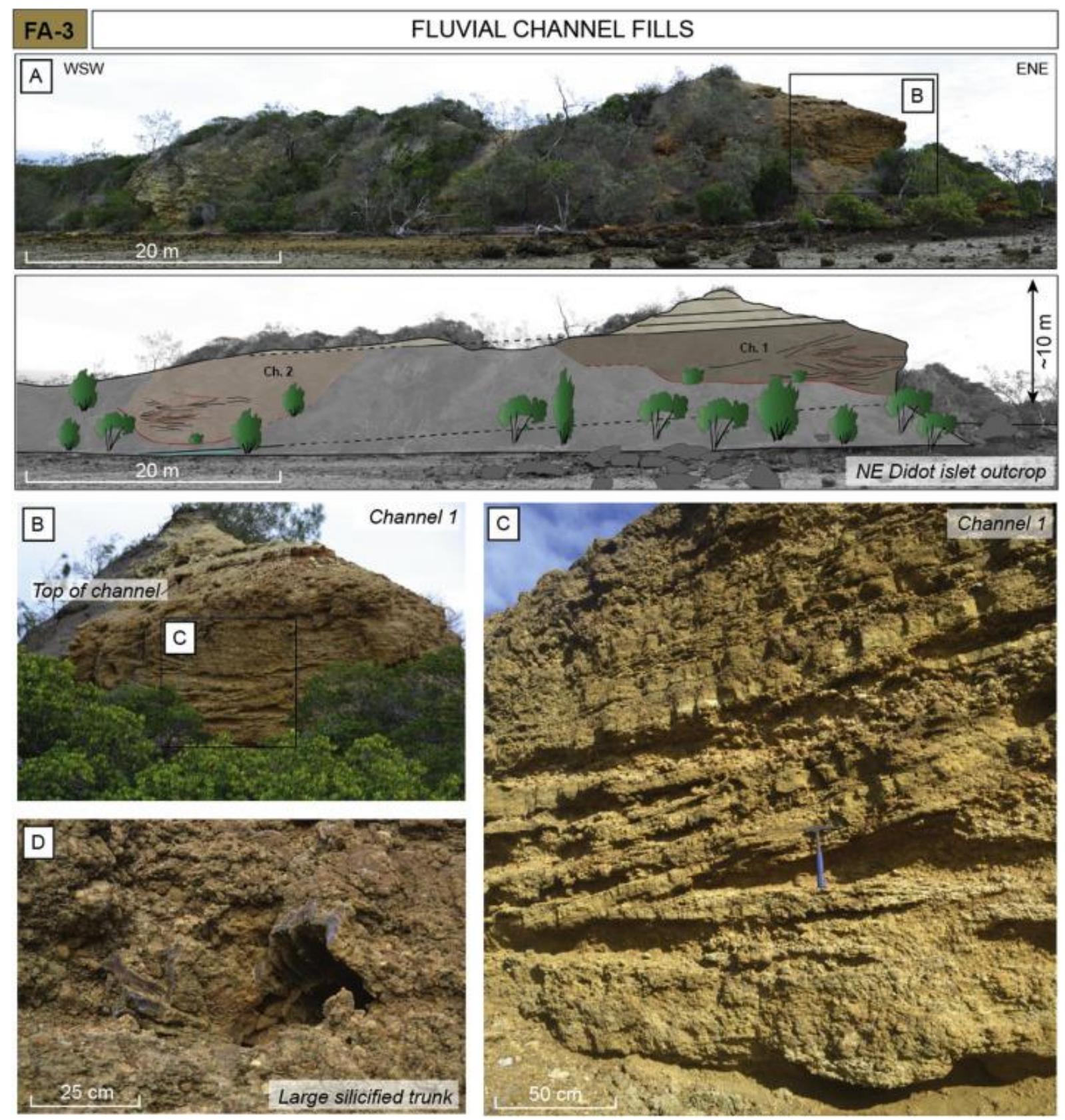
Figure 9

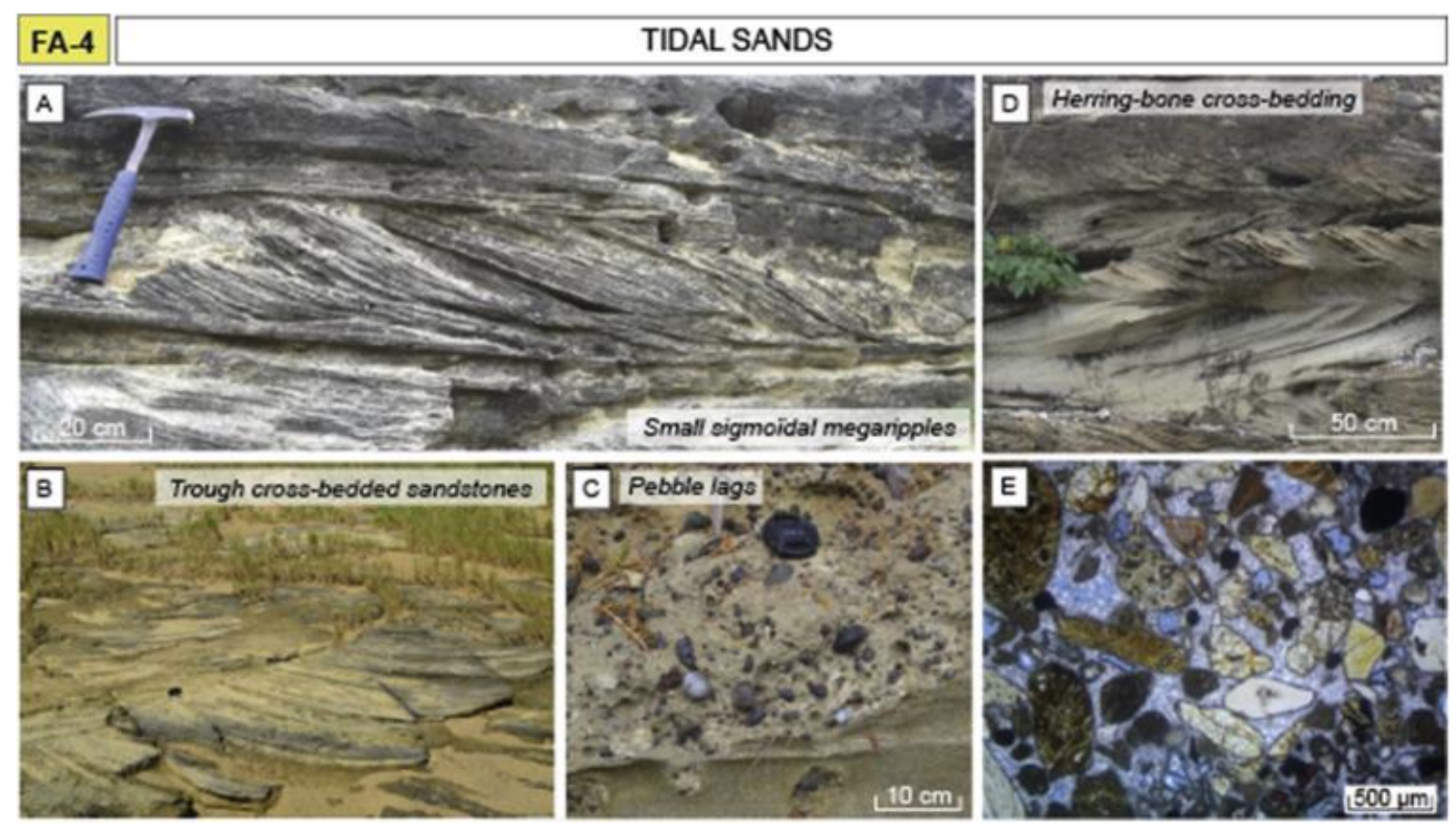

Figure 10

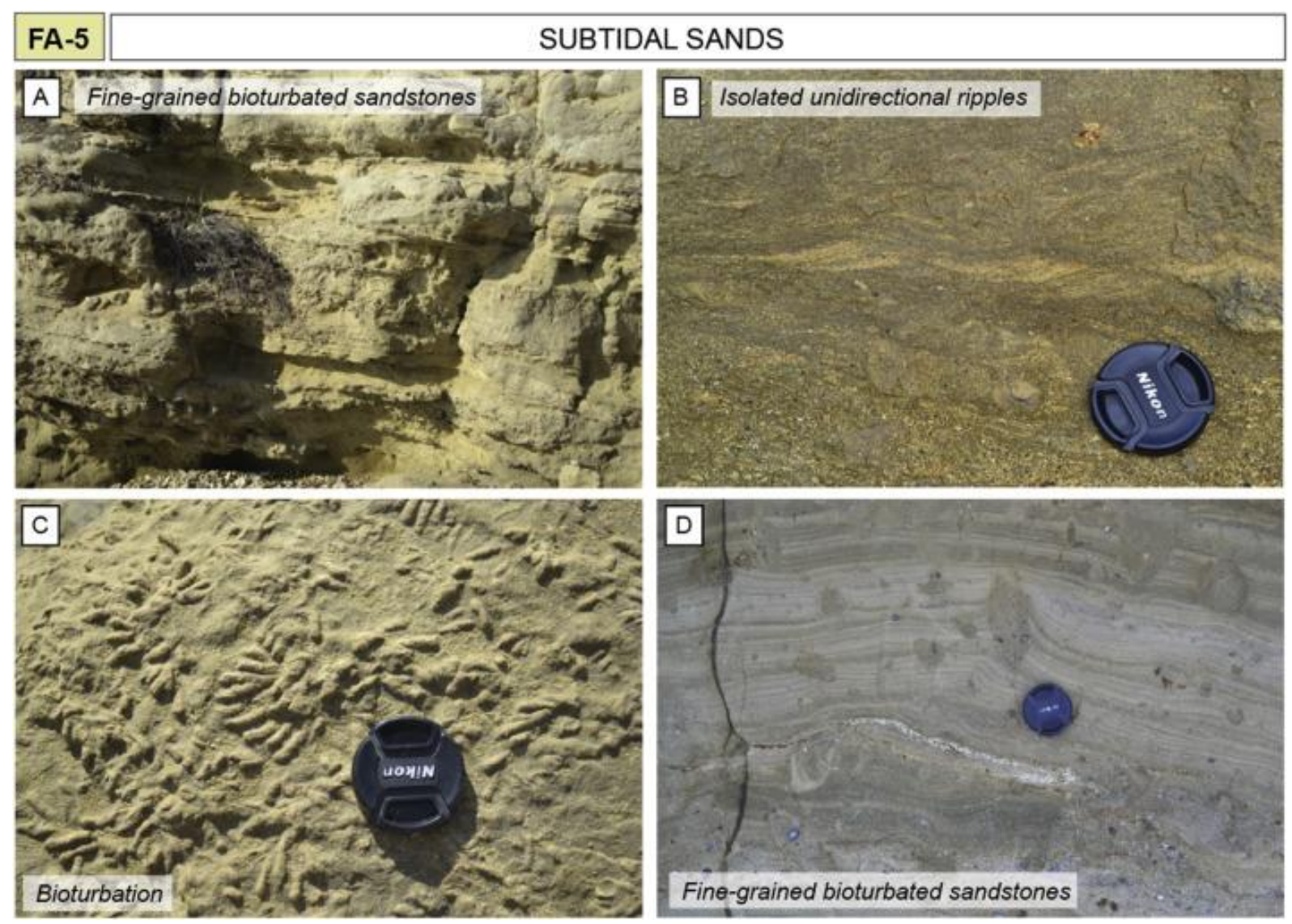


Figure 11
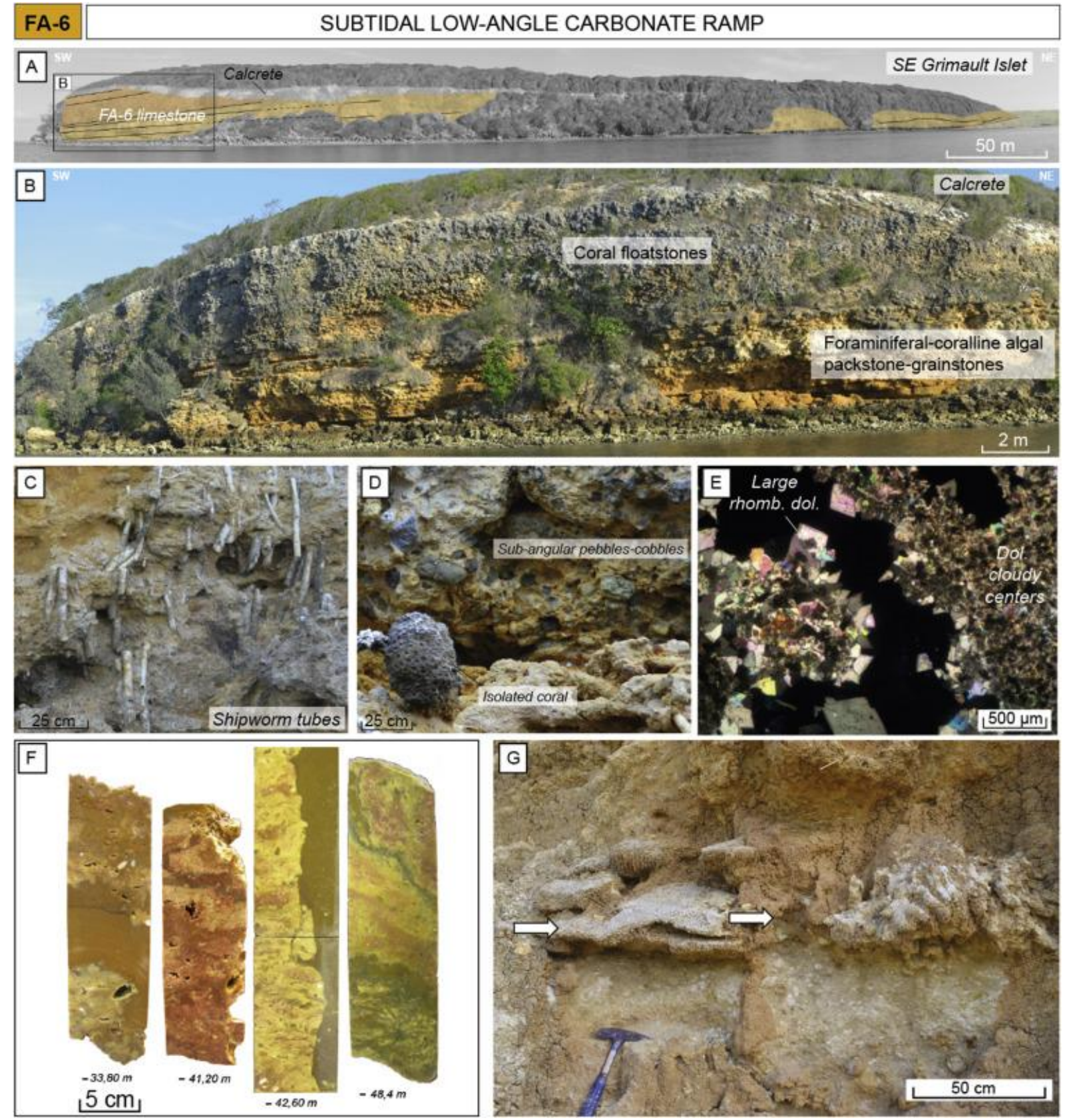
Figure 12

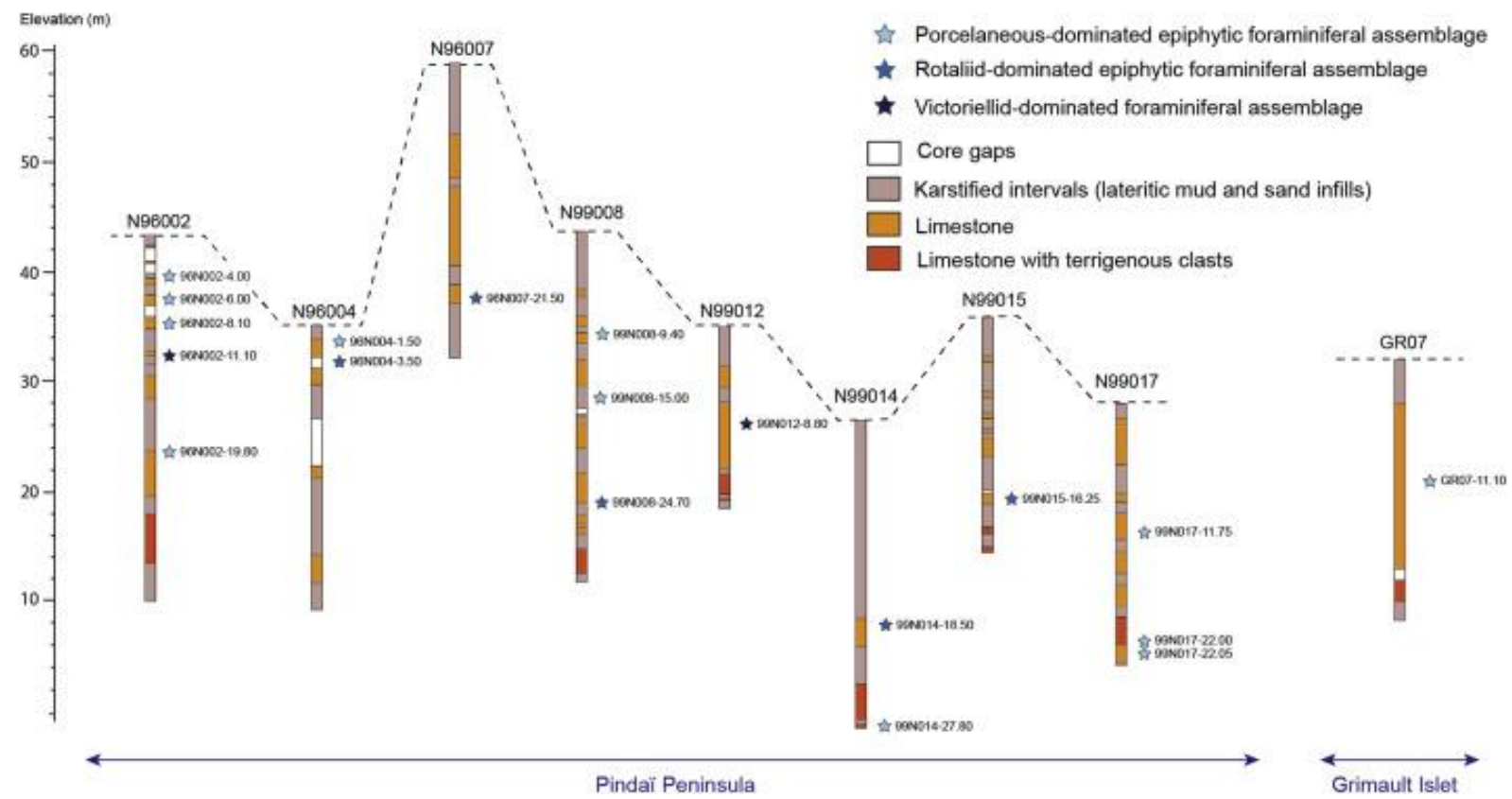


Figure 13
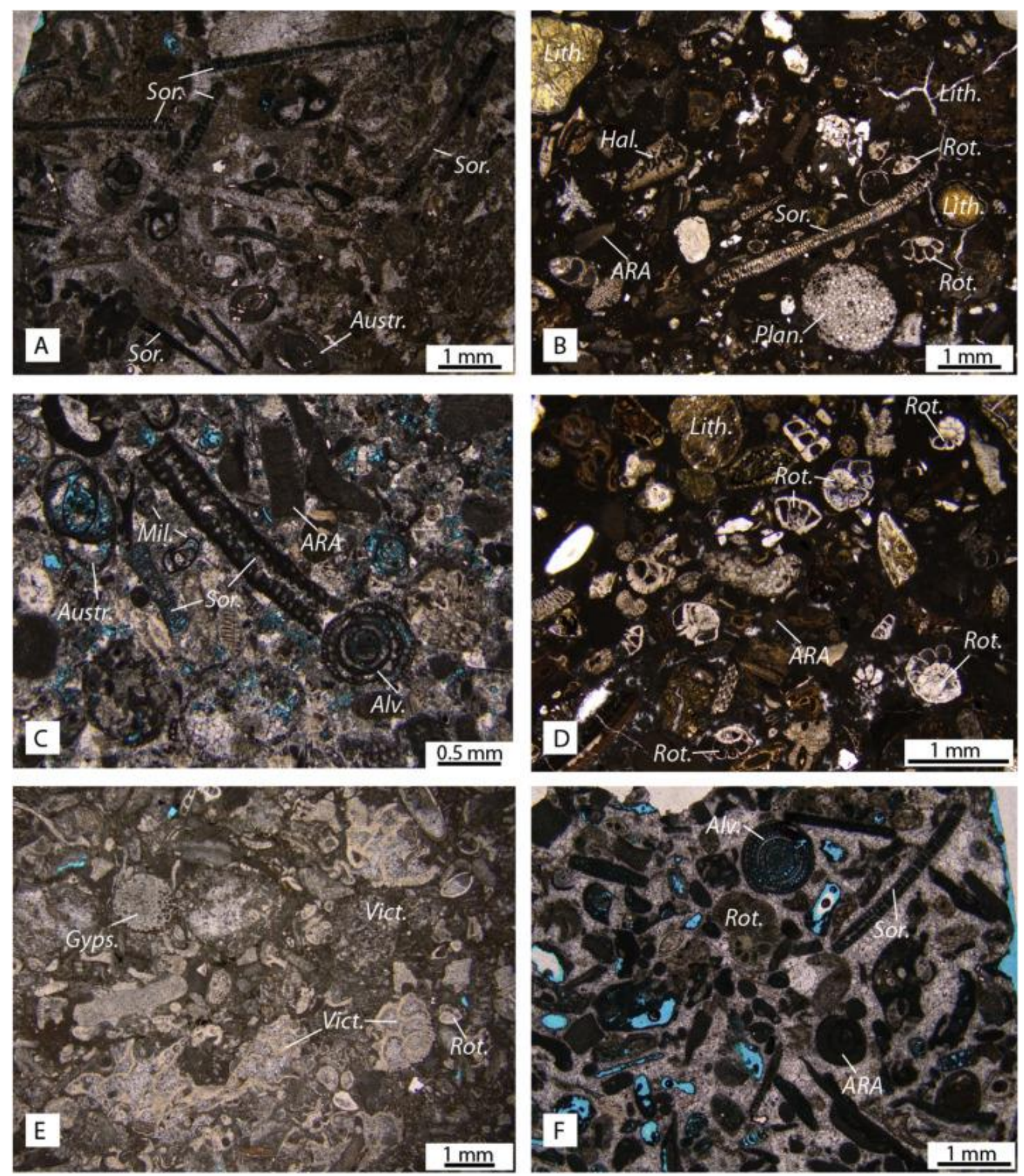
Figure 14

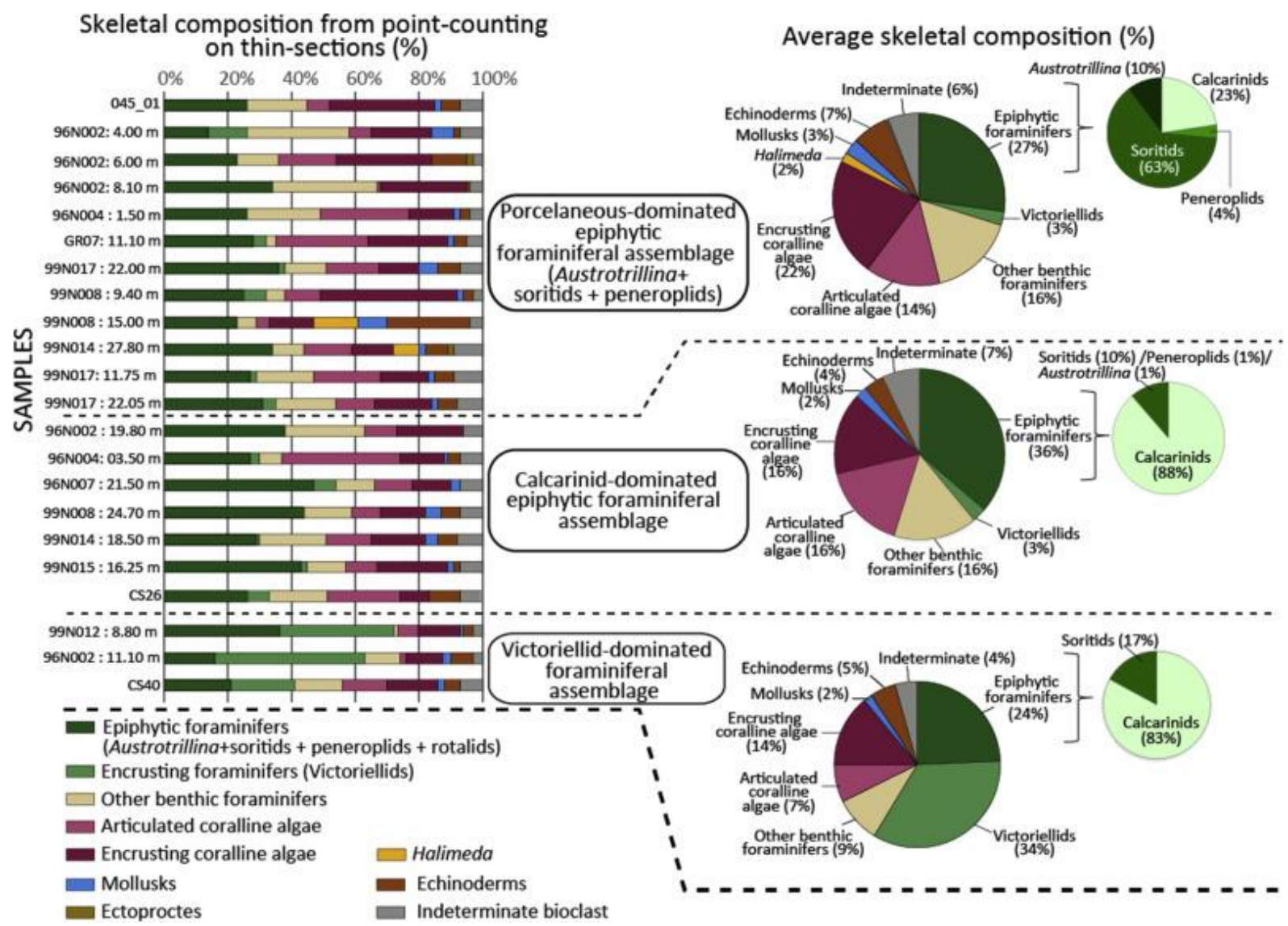


Figure 15
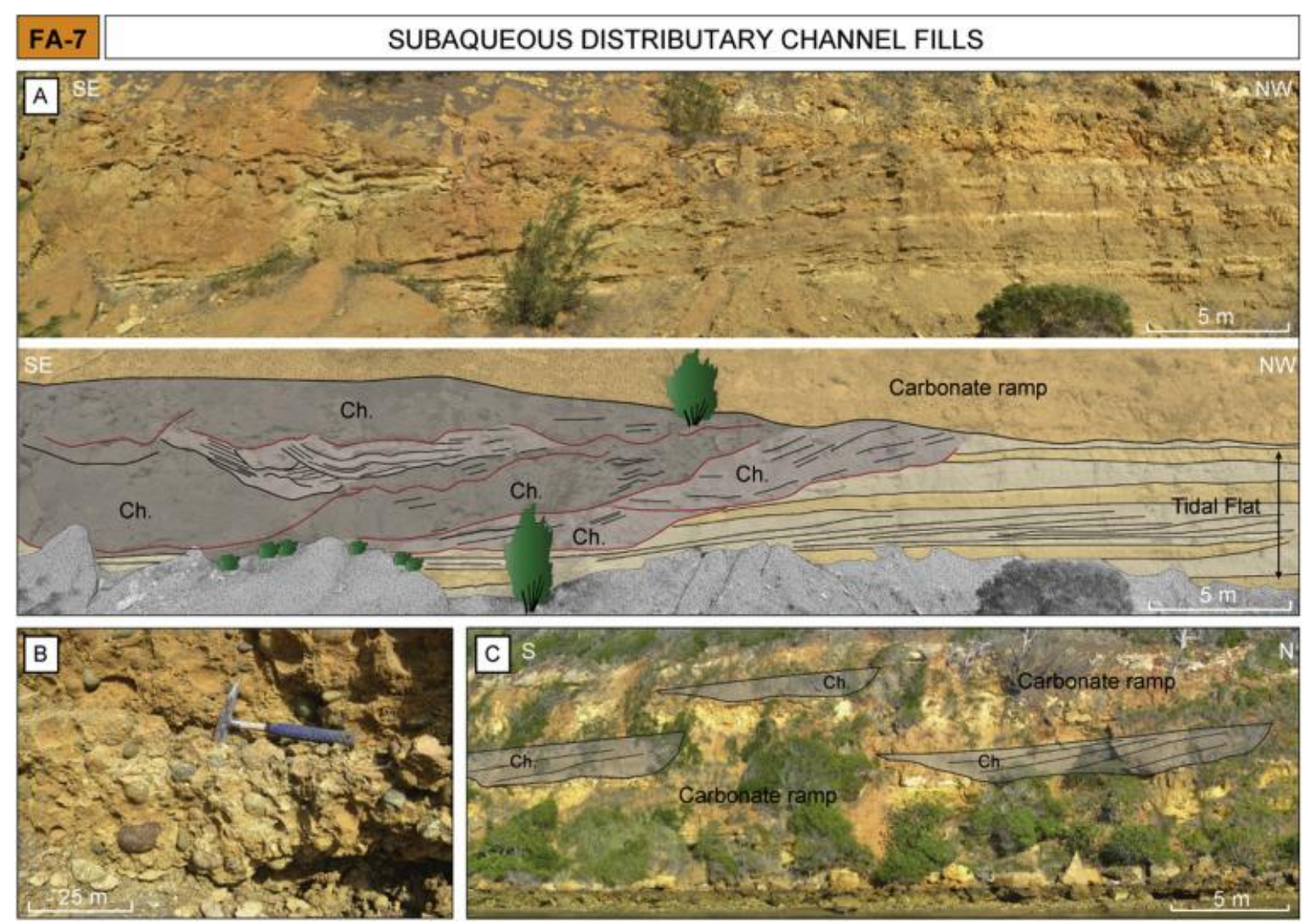
Figure 16

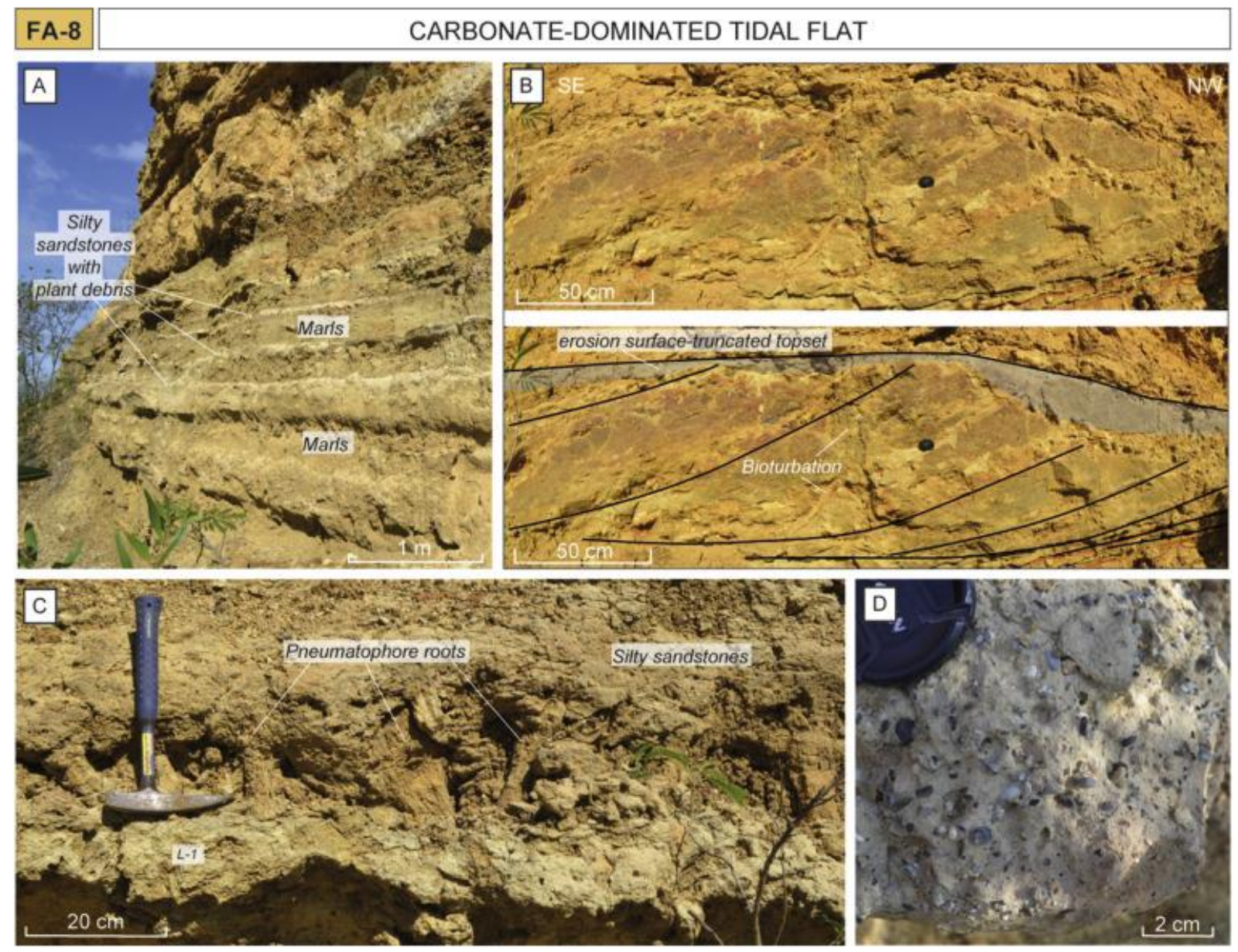


Figure 17

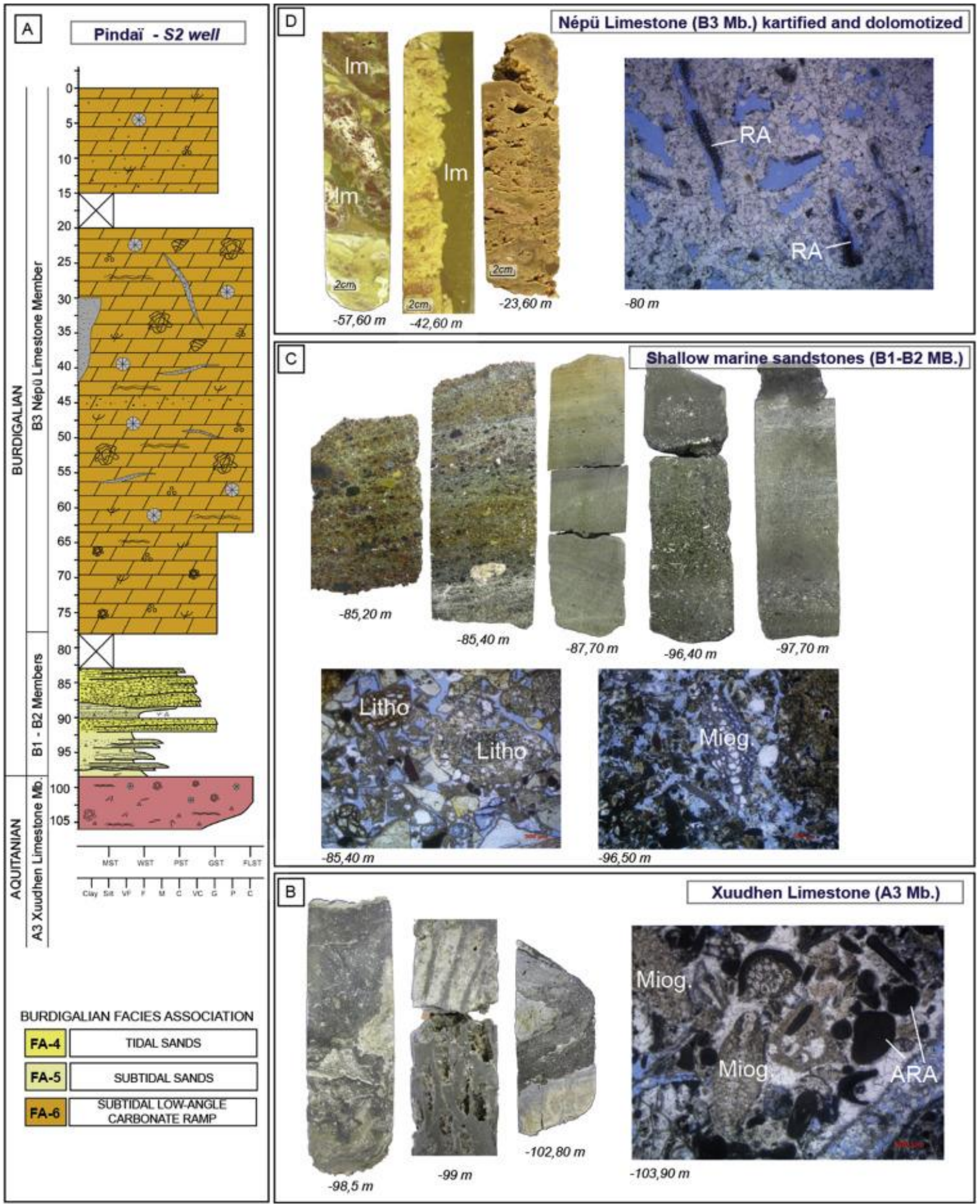


Figure 18

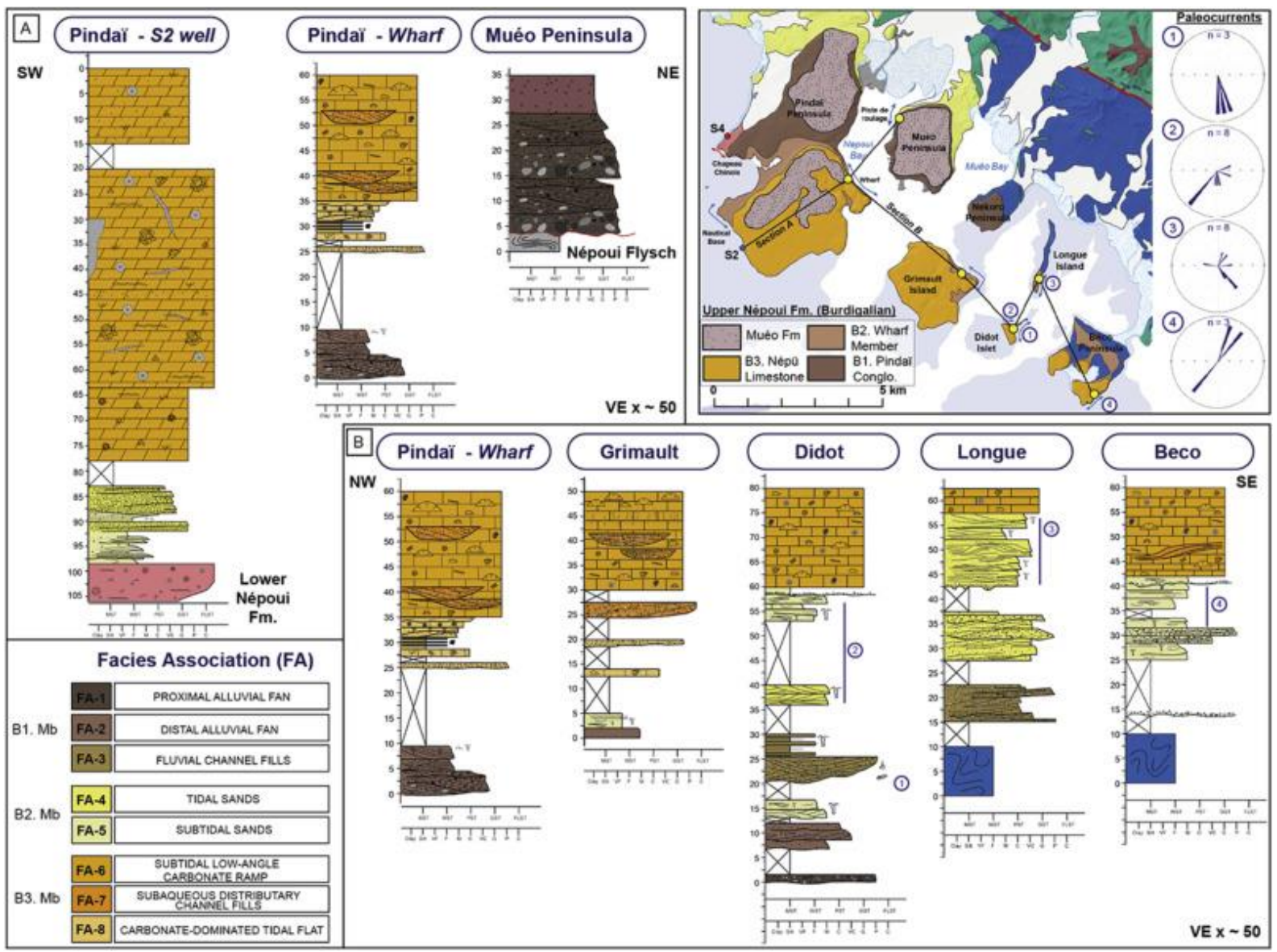


Figure 19
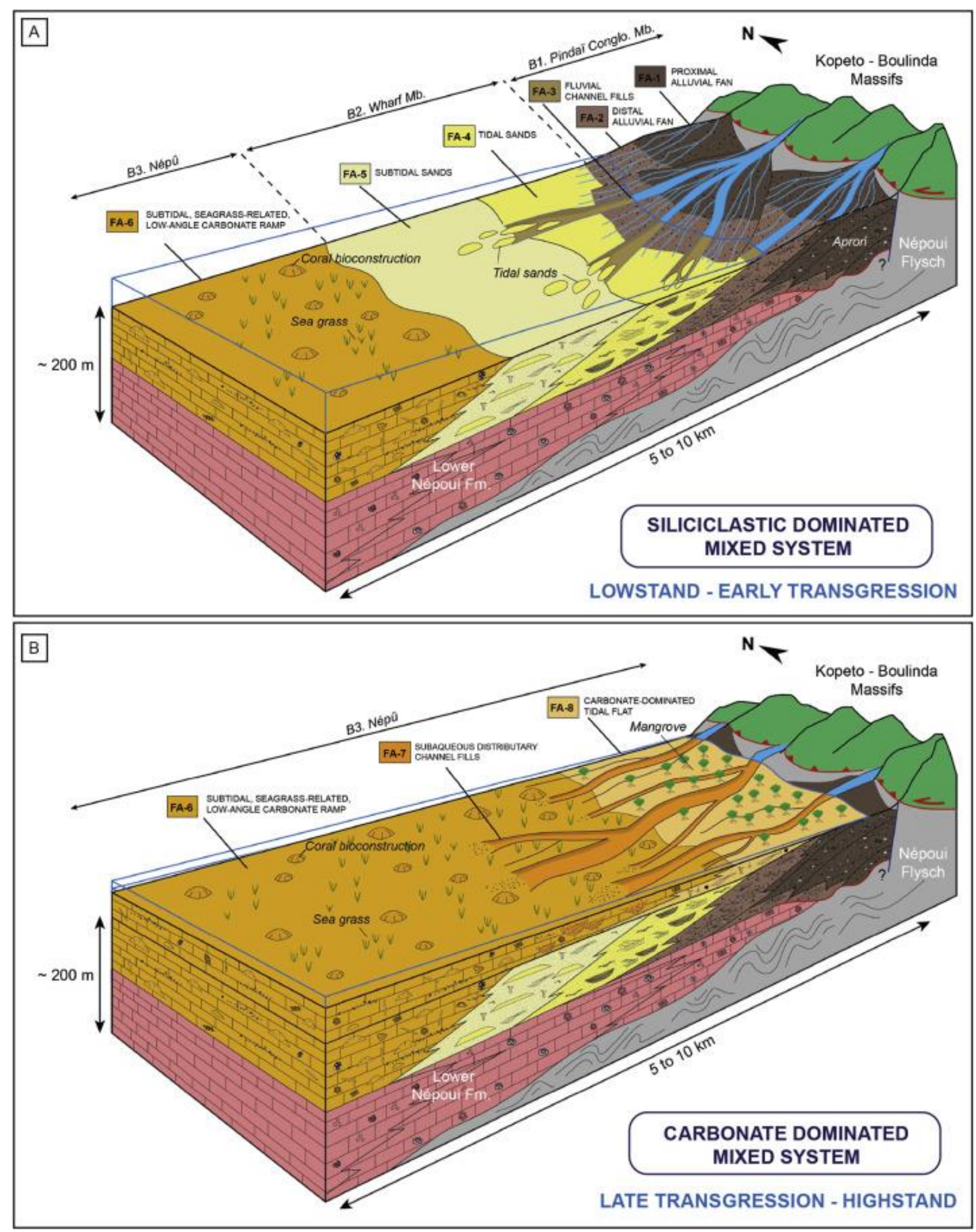